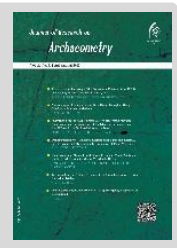

\title{
The field monitoring of influential biodeteriogenic Agent the historic rock surfaces in Persepolis-UNESCO World Heritage Site
}

\author{
Mohammad Sohrabi ${ }^{1 \star}$, Mahsa Esmaeillou²,Hamid Fadaei ${ }^{3}$, Mohammad Hassan Talebian $^{4}$, \\ Nasrin Noohi ${ }^{3}$ \\ ${ }^{1}$ Assistant Professor in Iranian Research Organization for Science and Technology, \& The Museum of \\ Iranian Lichens, Tehran, IRAN \\ ${ }^{2}$ PhD student in Microbiology, Iranian Research Organization for Science and Technology, Tehran, IRAN \\ ${ }^{3}$ Assistant Professor in Research Center for Conservation of Cultural Relics, Research Center of Iranian \\ Cultural Heritage and Tourism Organization, Tehran, IRAN \\ ${ }^{4}$ Architectural Conservation, Associate Professor in Department of Fine Arts, University of Tehran, IRAN,
}

Received: $21 / 02 / 2020$

Accepted: 09/06/2020

\begin{abstract}
Cultural heritage has always been the focus of many civilizations and therefore, it needs to be preserved for future generations. From prehistoric times, when grandeur and beauty were the aims of architecture, stone was the most widely used durable material. Biodeterioration of the stone monuments, one of the most important causes for the loss of the cultural heritage, is defined as any undesirable change in the properties of a material caused by the action of biological agents such as fungi, bacteria, cyanobacteria, lichens and plants, as well as animals such as insects. The world heritage of Persepolis, for example, has been unprotected from biodeterioration for the centuries, and has unfortunately not been addressed during this time. The purpose of this study is to provide a new perspective on the study of the destructive biological factors affecting this historic site to provide a framework for future studies and serious consideration of the biological debate in conservation and restoration issues. Therefore, the presence of various factors possibly derived from the action of animals, vascular plants, mosses, fungi, lichens, green microalgae, and photosynthetic and non-photosynthetic bacteria were investigated. Based on objective observations, the presence of biodegradation factors affecting floors and the all sides of walls of various buildings in Persepolis was qualitatively investigated. Based on the results, the studied areas were classified into four classes with very high, high, medium and low risk. In addition to the initial estimate of biodiversity, the factors affecting the biodegradation of Persepolis were presented for the first time and the critical points for the presence of destructive factors were determined. Lichens exist throughout Persepolis and have proved useful in archaeological studies, since their growth can be chronologically employed to measure the age of rocks and indeed ancient monuments, their radial growth increasing logarithmically over time based on the assumed specific rate. In this study, the presence of lichens has been investigated from the perspective of biodeterioration, their presence at the microscopic scale can intensify the weathering and biodeterioration of the rock. Such action is not visible to the naked eye but leaves irreparable damage to the stone surface. It was estimated that this complex process at Persepolis is the result of more than 15 different Vascular plant species and
\end{abstract}

*Corresponding author: sohrabi@irost.org

Copyright $(2020$, the Authors / This open-access article is published under the terms of the Creative Commons Attribution-NonCommercial 4.0 International License which permits Share (copy and redistribute the material in any medium or format) and Adapt (remix, transform, and build upon the material) under the AttributionNonCommercial .terms 
5 Non-vascular plant (mosses), 16 or 17 different species of birds, 3 to 5 species of snails and 2 to 4 species of reptiles and insects. It was shown that the establishment of a biomonitoring laboratory at Persepolis is the important task of studying the action of microorganisms since it is estimated that more than 20 strains of non-photosynthetic bacteria, more than 10 taxa of cyanobacteria, about 15 plants and mosses, more than 130 lichen species and 20 species of non-lichen fungi are involved in the biodegradation of Persepolis. The results are the estimative and provide the basis for more detailed studies to monitor the factors involved in biodegradation, which is one of the necessities of this World Heritage Site.

Keywords: XRD, Persepolis, Biodeterioration, Conservation and Restoration, World Cultural Heritage, Critical points, Biodiversity. 


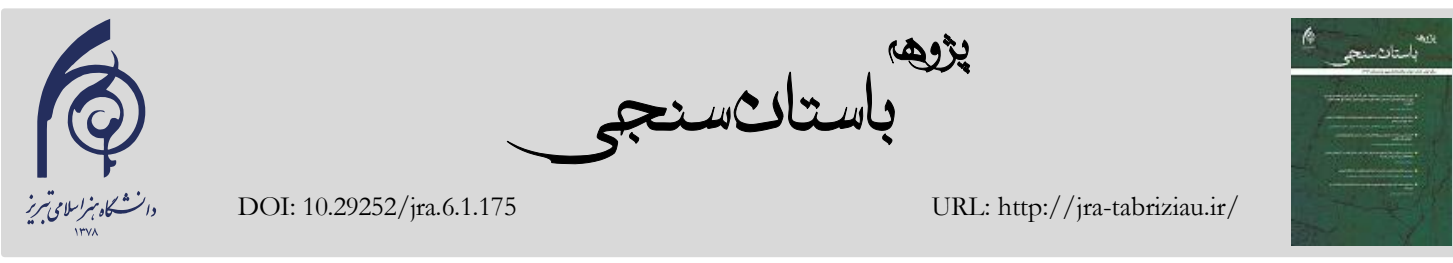

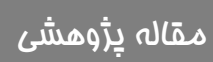

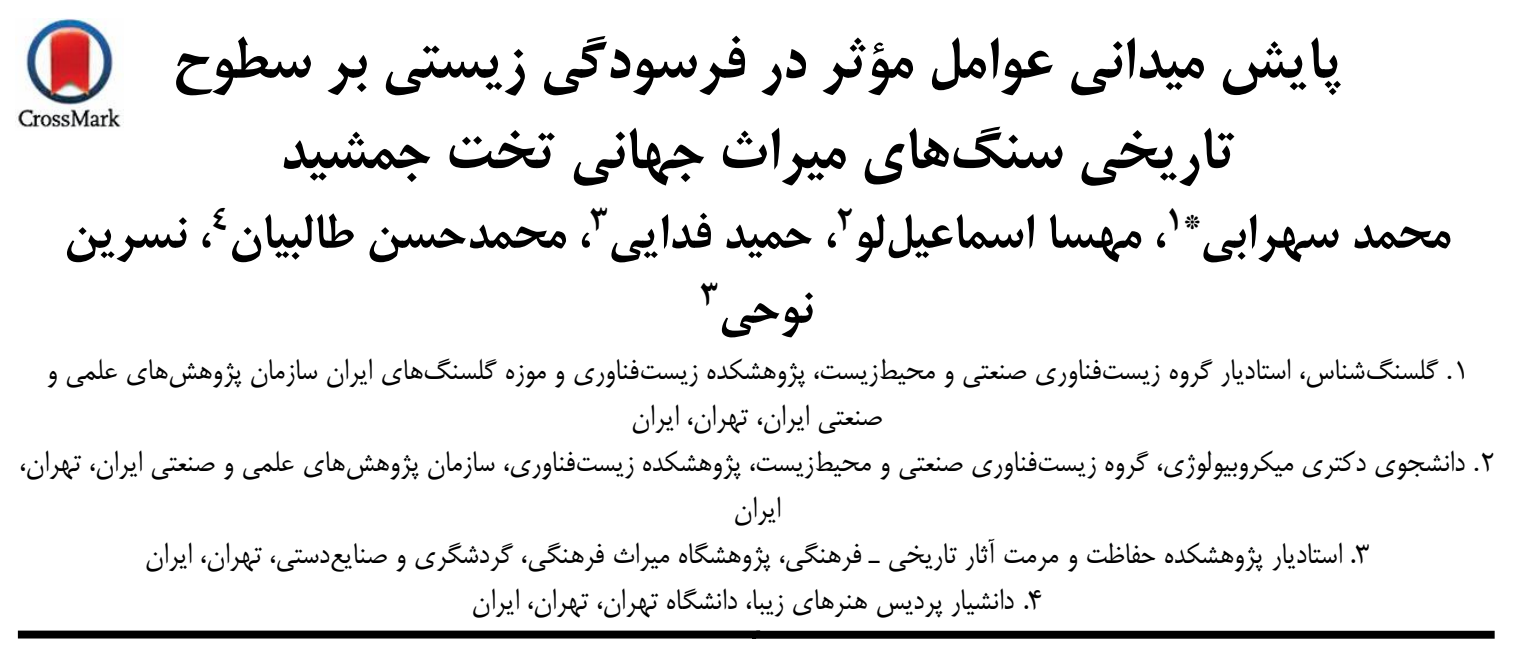

تاريخ بِيرش:

تاريخ دريافت: Pسر

جكيده

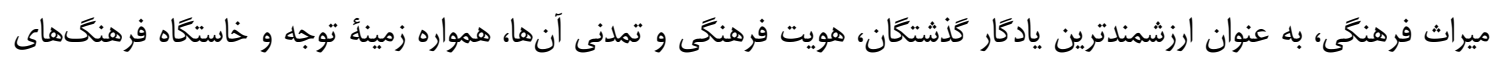

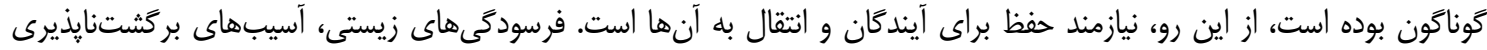

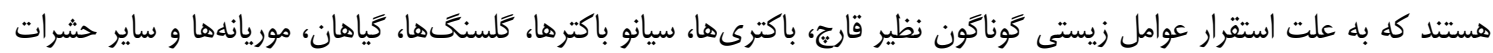

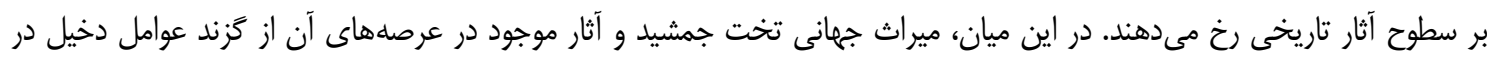

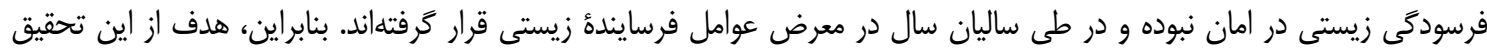

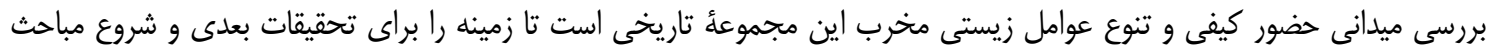

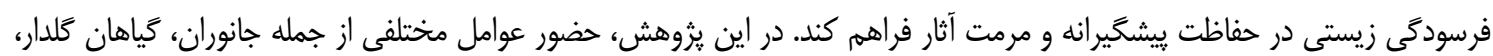
قارجها، كلسنگ

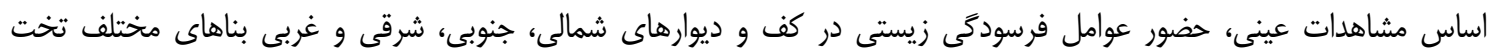

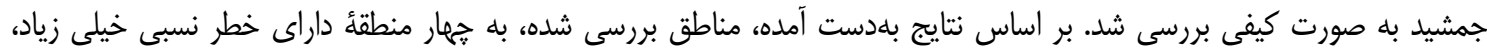

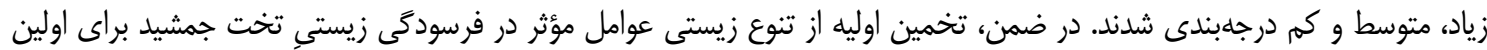

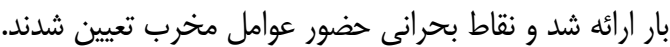
وازًَان كليدى: تخت جمشيد، فرسودگى زيستى، حفاظت و مرمت، ميراث جهانى، نقاط بحرانى، تنوع زيستى

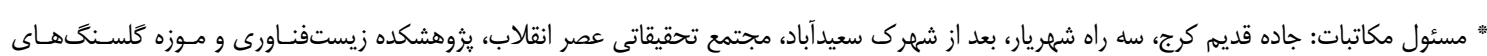

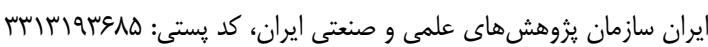
يست الكترونيكى: sohrabi@irost.org CC حق نشر متعلق به نويسنده(كان) است و نويسنده تحت مجوز Creative Commons Attribution License به مجله اجازه مى دهد مقاله جاب شده را با ديخران به اشتراك بكذارد منوط بر اينكه حقوق مؤلف اثر حفظ و وبه به انتشار اوليه مقاله در اين مجله اشاره شود. 
كَياهشناسى، باكترىشناسى، قارجشناسى، كلسنخشناسىى

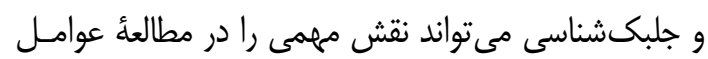

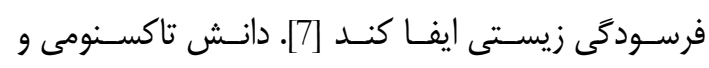
سامانمند مربوط به عوامل فرسودگى زيستى، كه در سطح

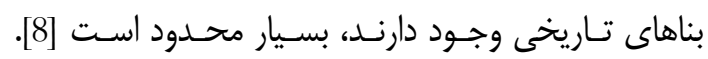

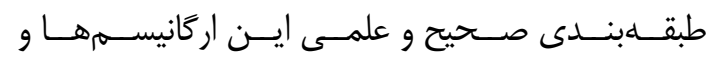

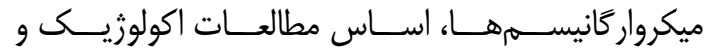

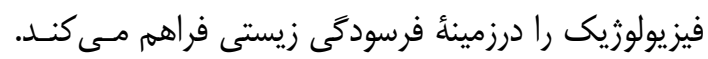
هر يك از اين عوامل داراى مكانيسمهاى زيستى تكثير و ورئي

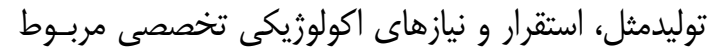

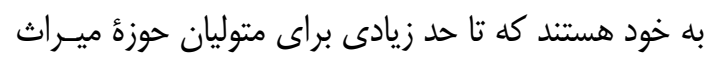

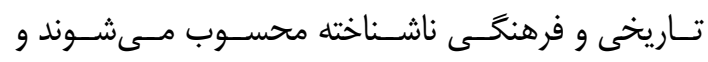

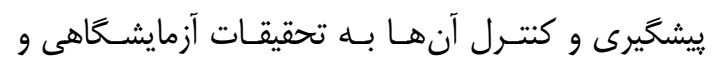
دانشخاهى زيادى، نياز دارد [9].

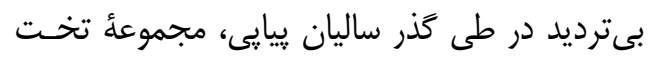

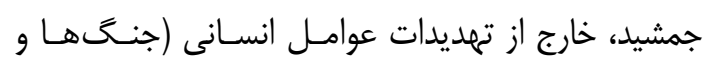

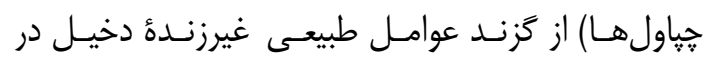

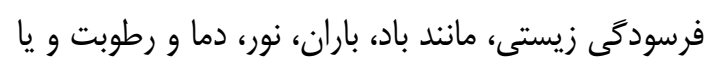

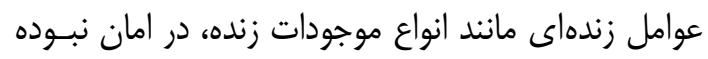

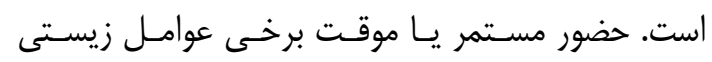

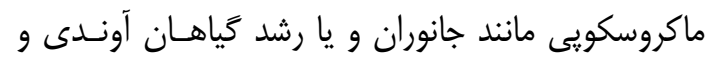

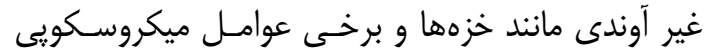

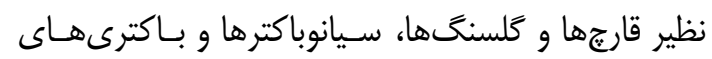
غير فتوسنتز كننده، نقوش هنرى ريزودرشت حجارى

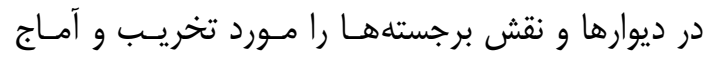

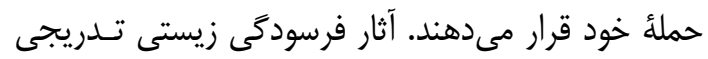

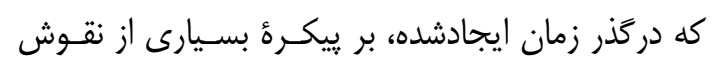

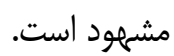

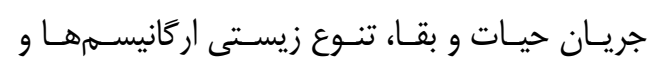

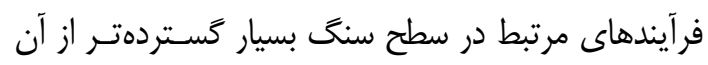

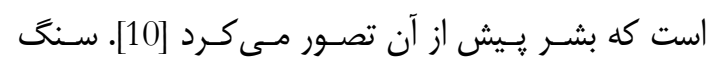

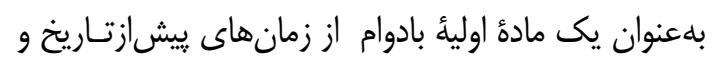

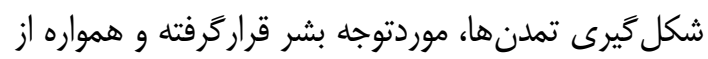

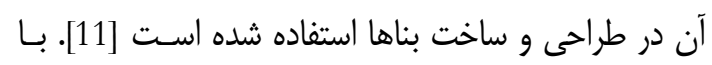

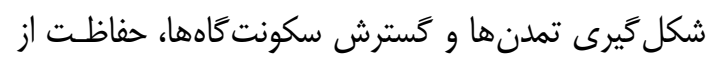

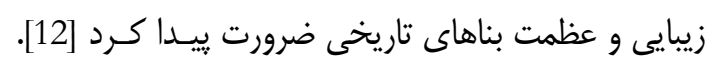

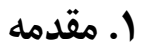

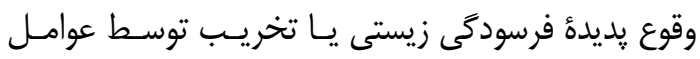

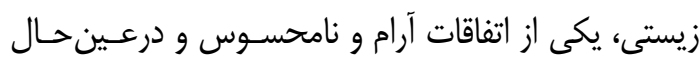

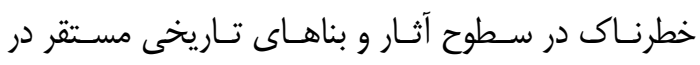

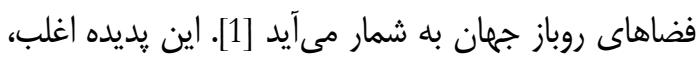

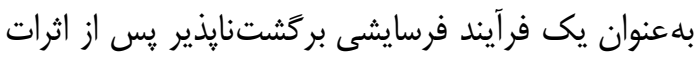

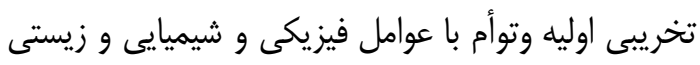

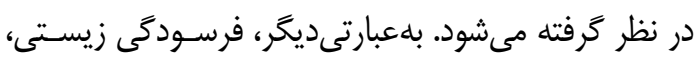

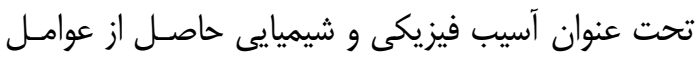

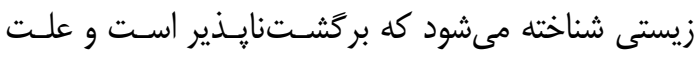

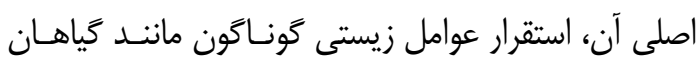

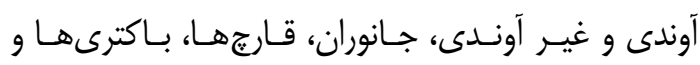

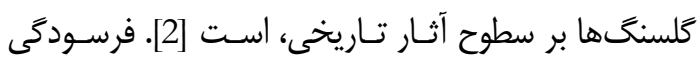

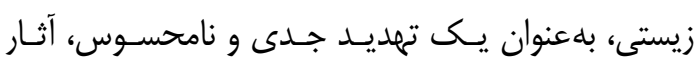

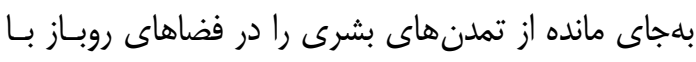

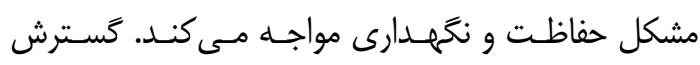

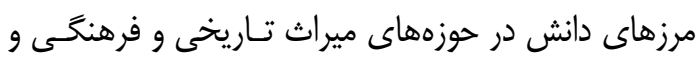

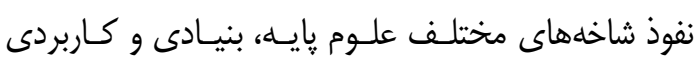

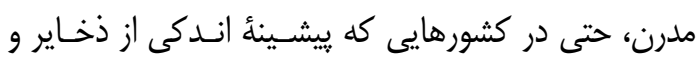

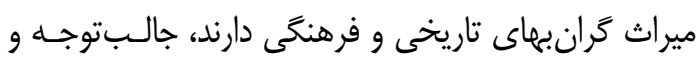

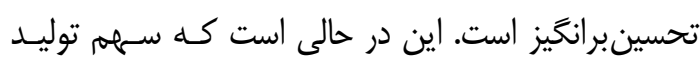
علوم يايه مرتبط با ميـراث فرهنتحى در كشـور مـا بسـيار

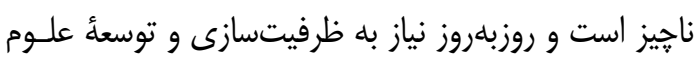
مدرن، در اين زمينه احسـاس مسىشـود. تنهـا حفـظ آثـار

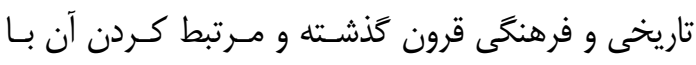

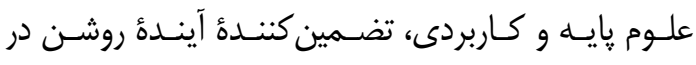

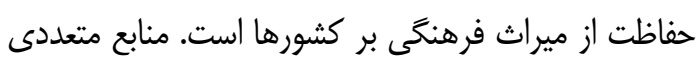

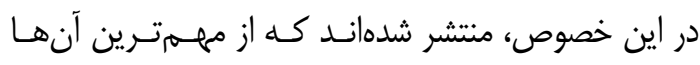

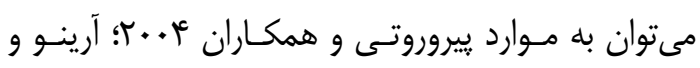

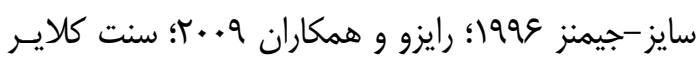

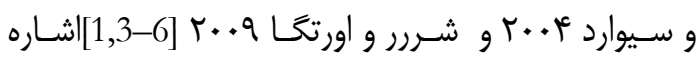

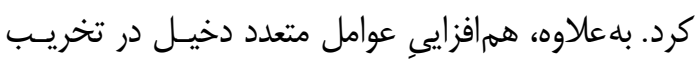

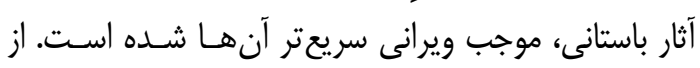

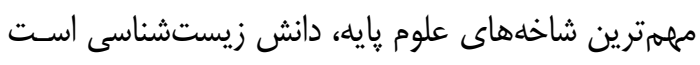

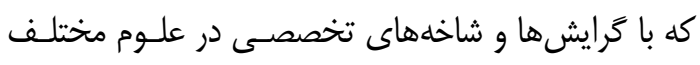

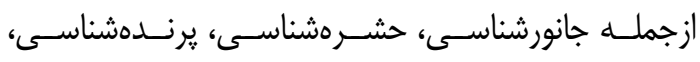




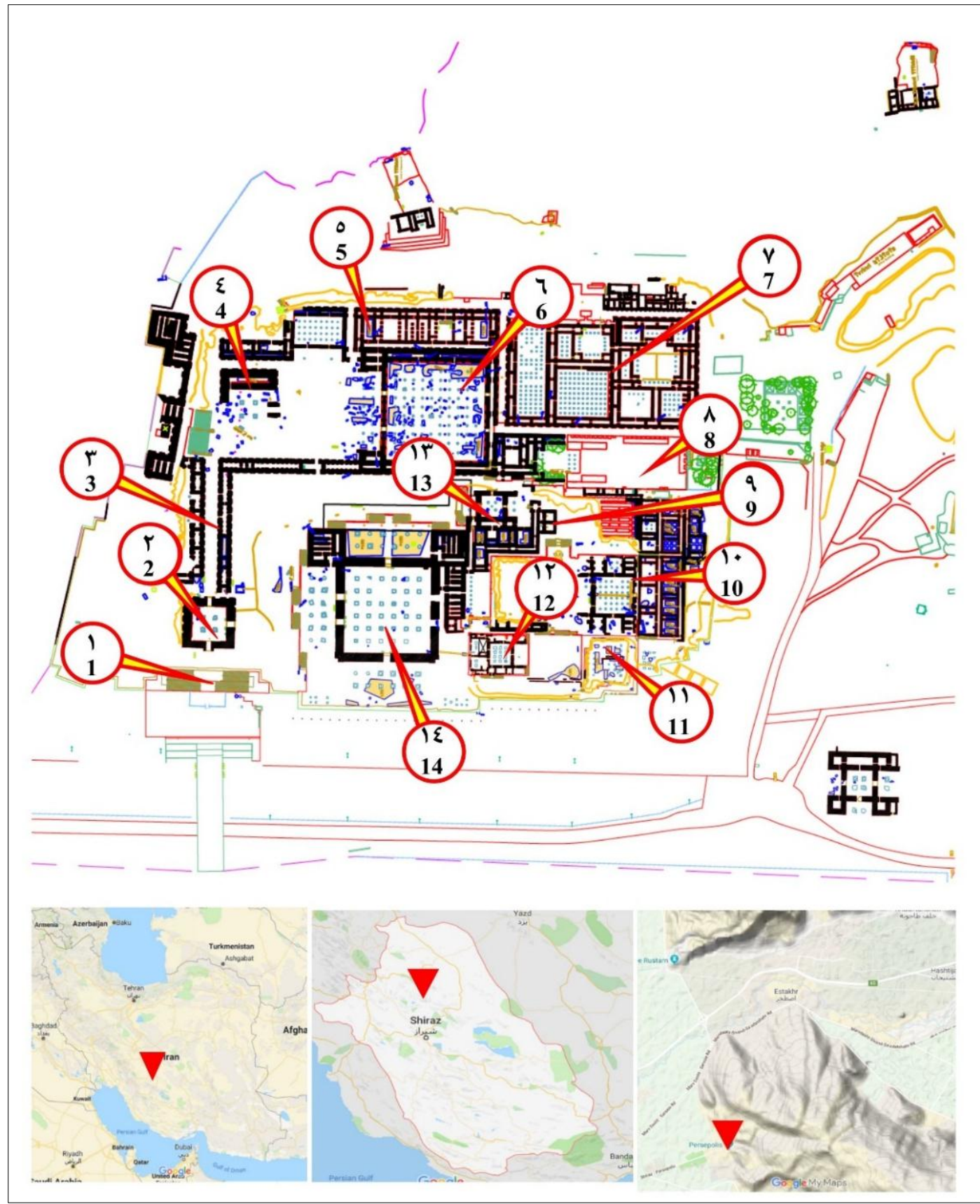

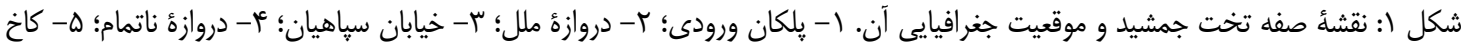

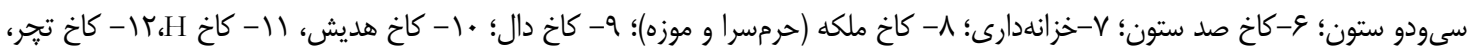

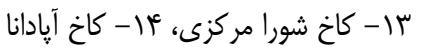

Fig.1: The map of Persepolis and its geographical location. 1) Main stairway; 2) The Gate of Nations; 3) Sepahian Street; 4) The Unfinished Gate; 5) 32-columned Hall; 6) Hall of a Hundred Columns; 7) Treasury; 8) Queen's palace (harem and museum); 9) Palace 'D'; 10) Hadish Palace; 11) Palace 'H'; 12) Thatcher Palace; 13) Central Palace; 14) Apadana Palace.

اصالت اين آثار ماندًار غيرقابل جايخزين، منحصربهفـرد و غيرقابل بر گشت است [13].

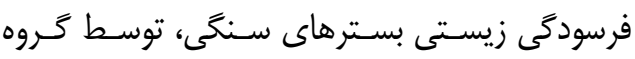

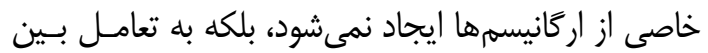

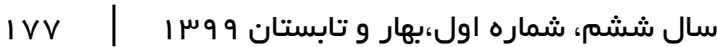

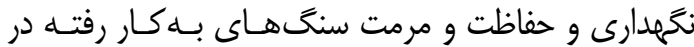

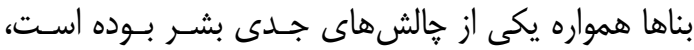

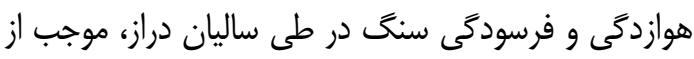

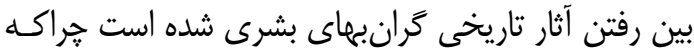




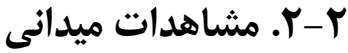

مشاهدات ميدانى و مستند نكارى اين تحقيق، از سالهاى

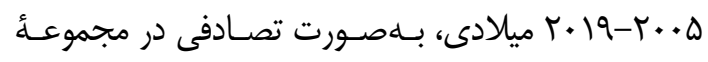
ميراث جهانى تخت جمشيد بر بائُ نقشههاى تهيهشده در

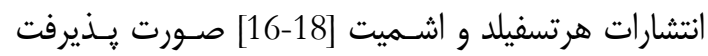

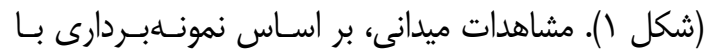

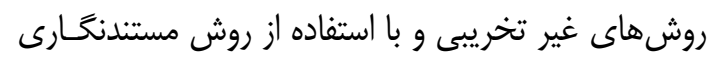

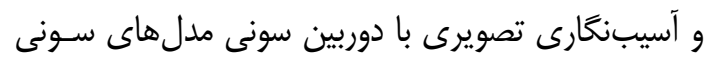

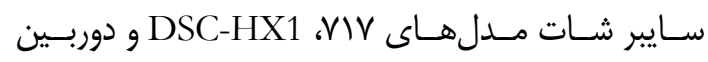
HS 9.Canon PowerShot SX بدون استفاده از فلش

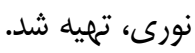

\section{r-r. مشاهدات ميكروسكوبى نورى}

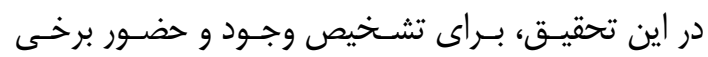

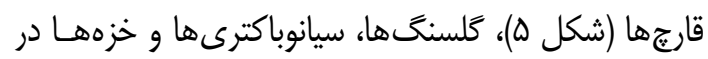

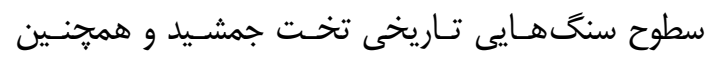

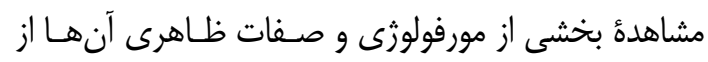

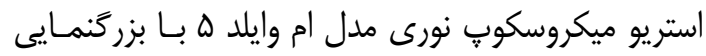

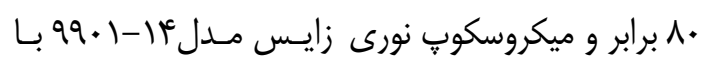

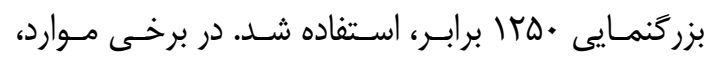

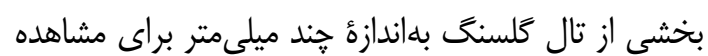

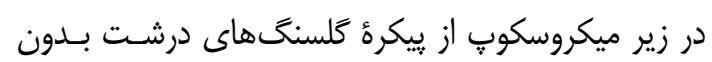

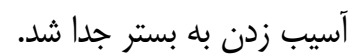

\section{ץ-ع. مشاهدات ميكروسكوب الكترونى}

در اين تحقيق، براى تشـخيص حضـور و فعاليـت برخى مئى

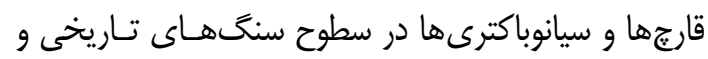

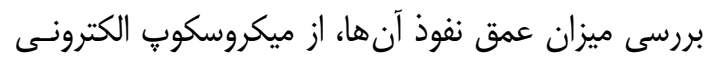

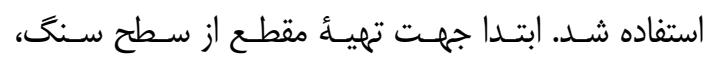

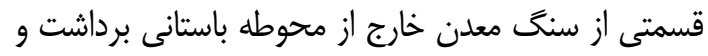

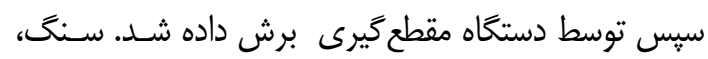
روى يودرهاى مخصوص از درشت تا ريز بــه ترتيـب و بـاــا

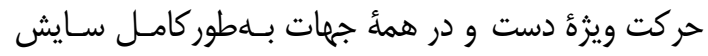

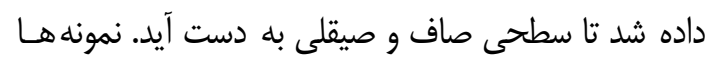

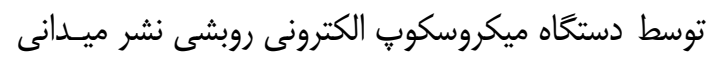

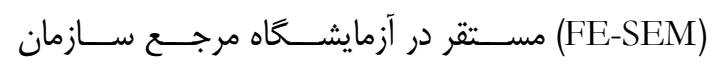

كروههاى همزيست مختلف بسـتخى دارد [8]. عـاوه بـر

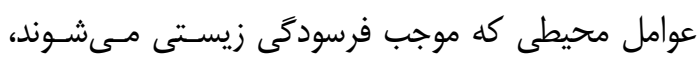

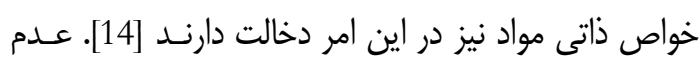

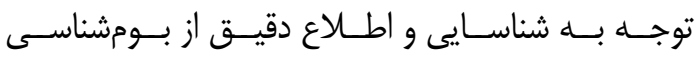

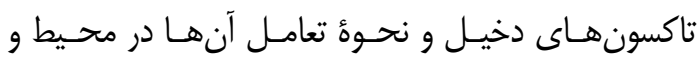

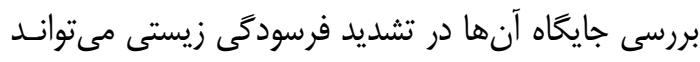

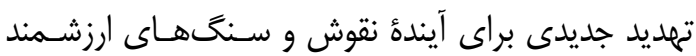

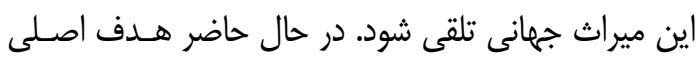

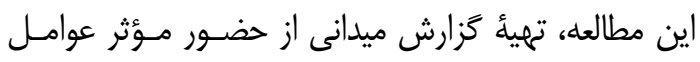

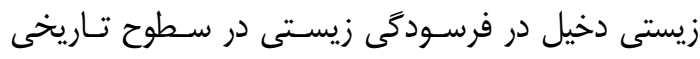

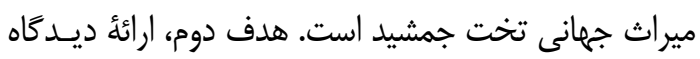

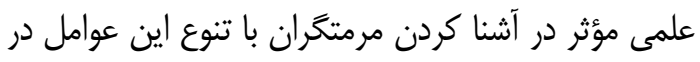

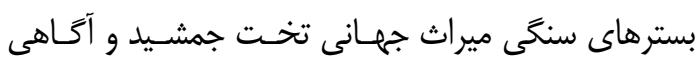

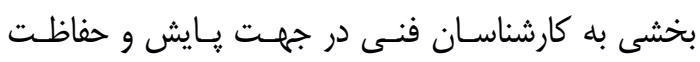
ي بيشخيرانه است.

\section{r. إد مواد و روشها}

\section{ץ- ا. موقعيت جغر افيايى تخت جمشيد}

تخت جمشيد در مركز استان فارس، دَه كيلومترى شـمال جمال

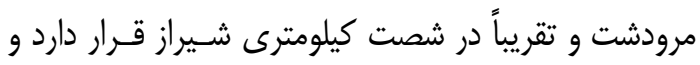

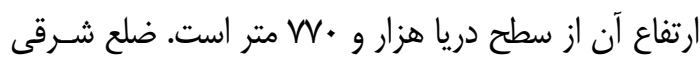

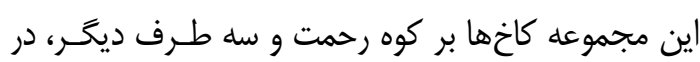

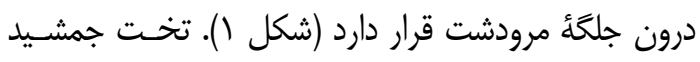

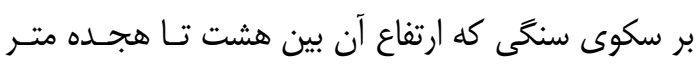

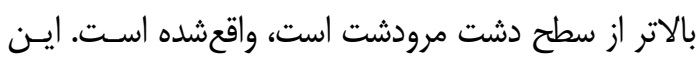

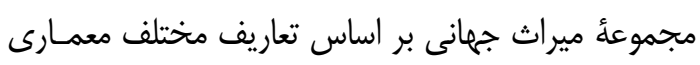

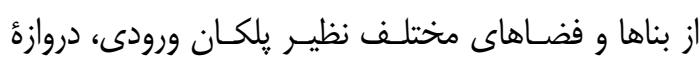

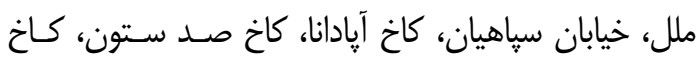

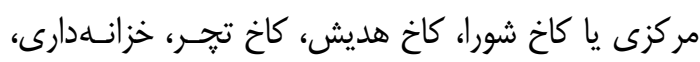

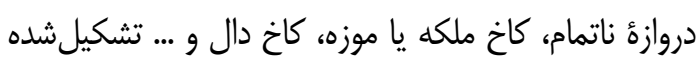

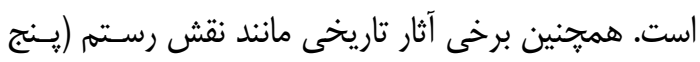

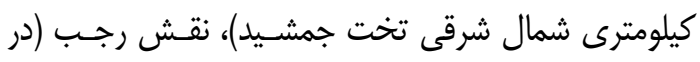

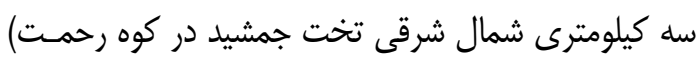

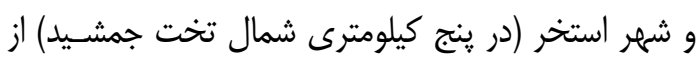

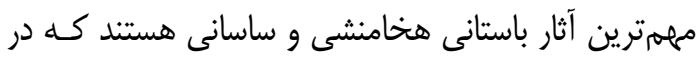
نزديكى تخت جمشيد قرار دارند [15,16].

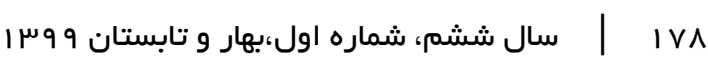


تاريخى مىشوند. عوامل ميكروسكويى شناسـيىشــــ در

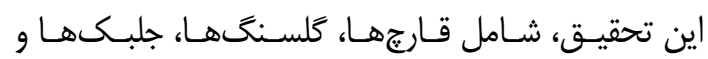

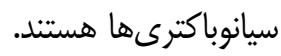

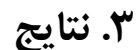

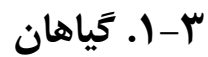

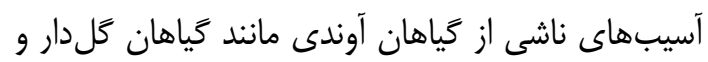

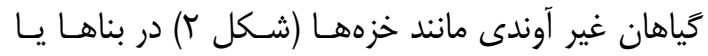
اماكن باستان شناسى بلاخوبى شناخته شده هستند. ميـران

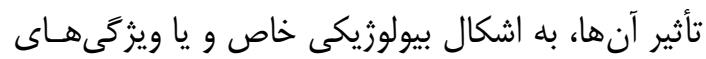

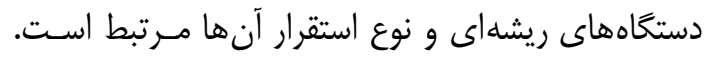

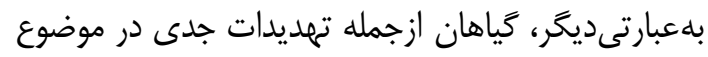
حفاظت و مرمت بناهاى تاريخى به شمار مى آينــــ زيـرا،

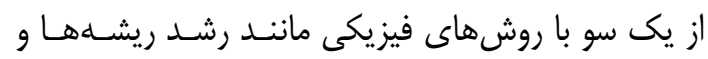

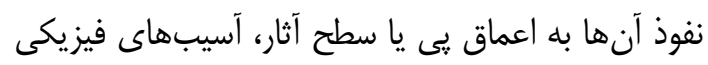

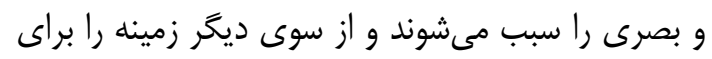

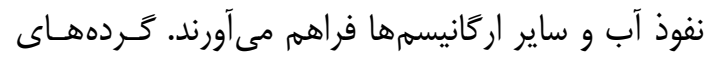

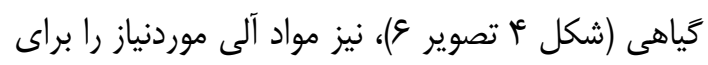

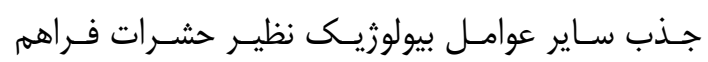

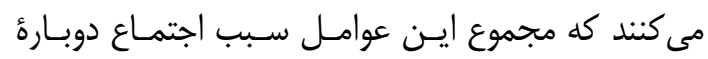

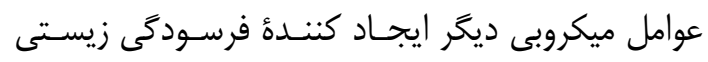

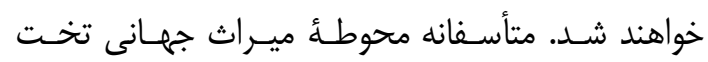

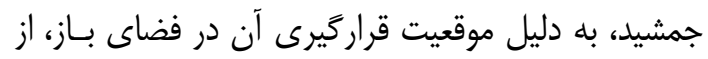

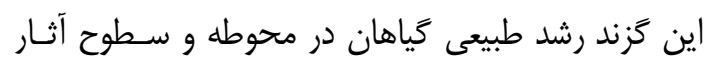
سنكى در امان نيست و با مشاهدات ميدانى فصلى كه كه از

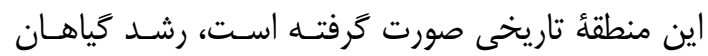

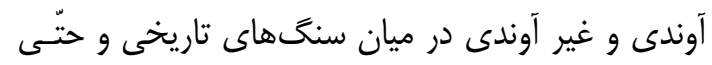

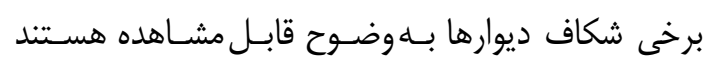
(شكل r تصاوير ا- (D).

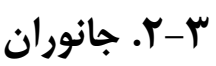

جانوران نقش مهمى را در بحـث فرسـودَّى زيسـتى ايفـا

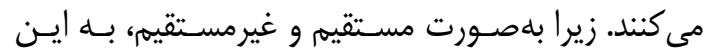

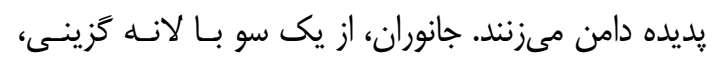

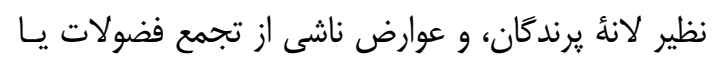

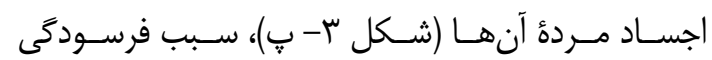

يزووهش هاى علمـى و صــنعتى ايــران، موردمطالهـهـ قـرار كرفتند. تصاوير با استفاده از در ولناز 15.00kv تصويربردارى شدند.

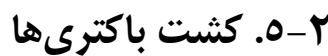

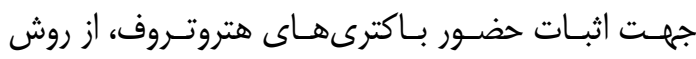

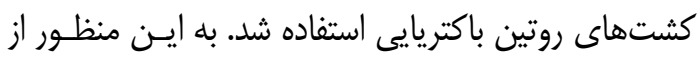

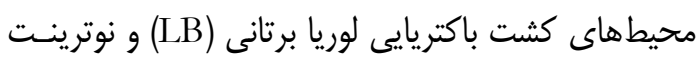

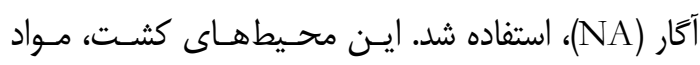

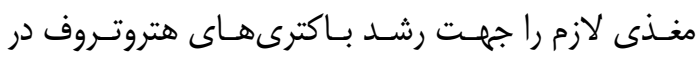

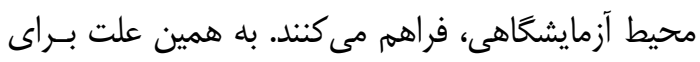

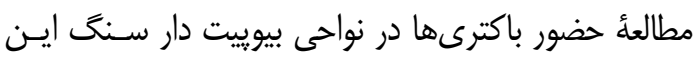

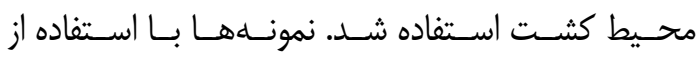

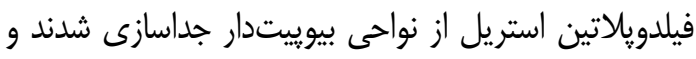

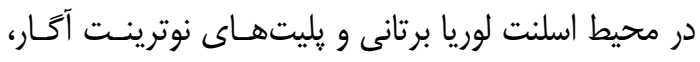

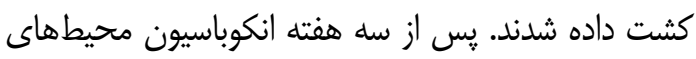

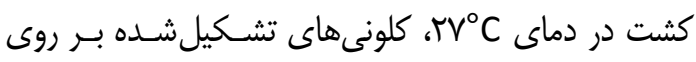
محيط هاى كشت ازنظر مورفولـوزيكى موردبررسى قـى قـرار

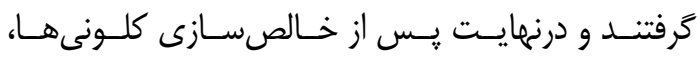

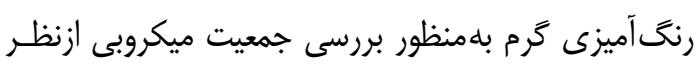

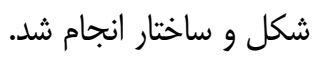

\section{ץ-7. طبقلبندى اركانيسمهاى دخيل در

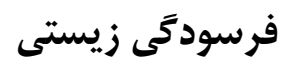

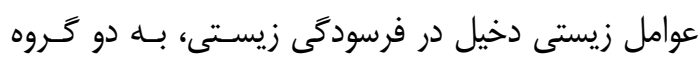

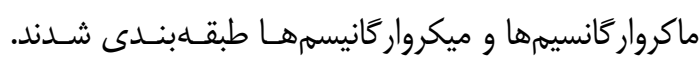
طبقابندى و تفكيى تروهى اين عوامل، بر اسـاس منـابع

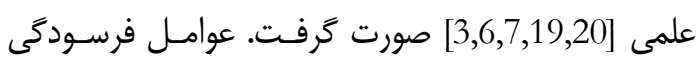

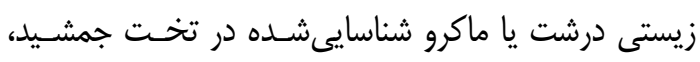

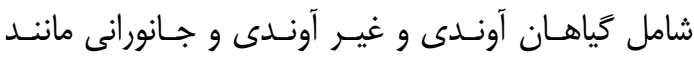

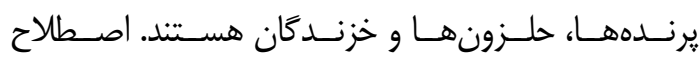

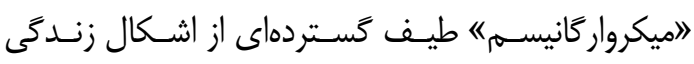

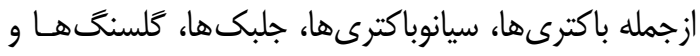

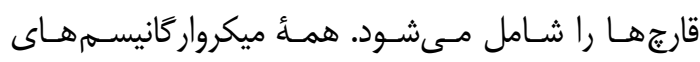

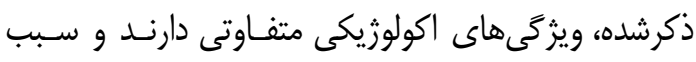
ايجاد خسارتهــاى مختلـف در مـواد آلى و معـدنى آثـار 
محوطة تاريخى تخت جمشيد از مشكل سازترين جـانوران

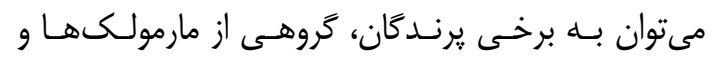

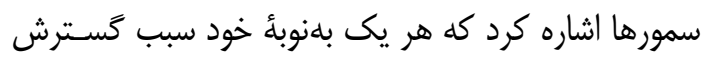

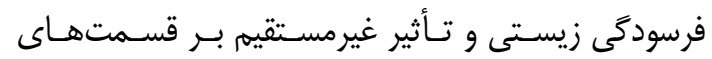
مختلف بنا مىشوند.
مى شوند. از سوى ديخر، فضولات آنها مواد آلى موردنيـاز

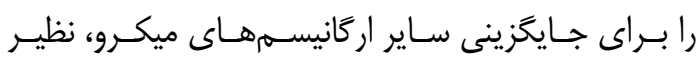

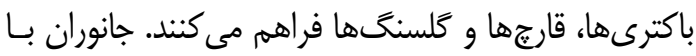

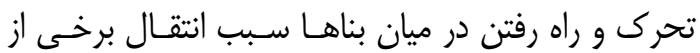

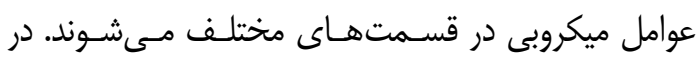

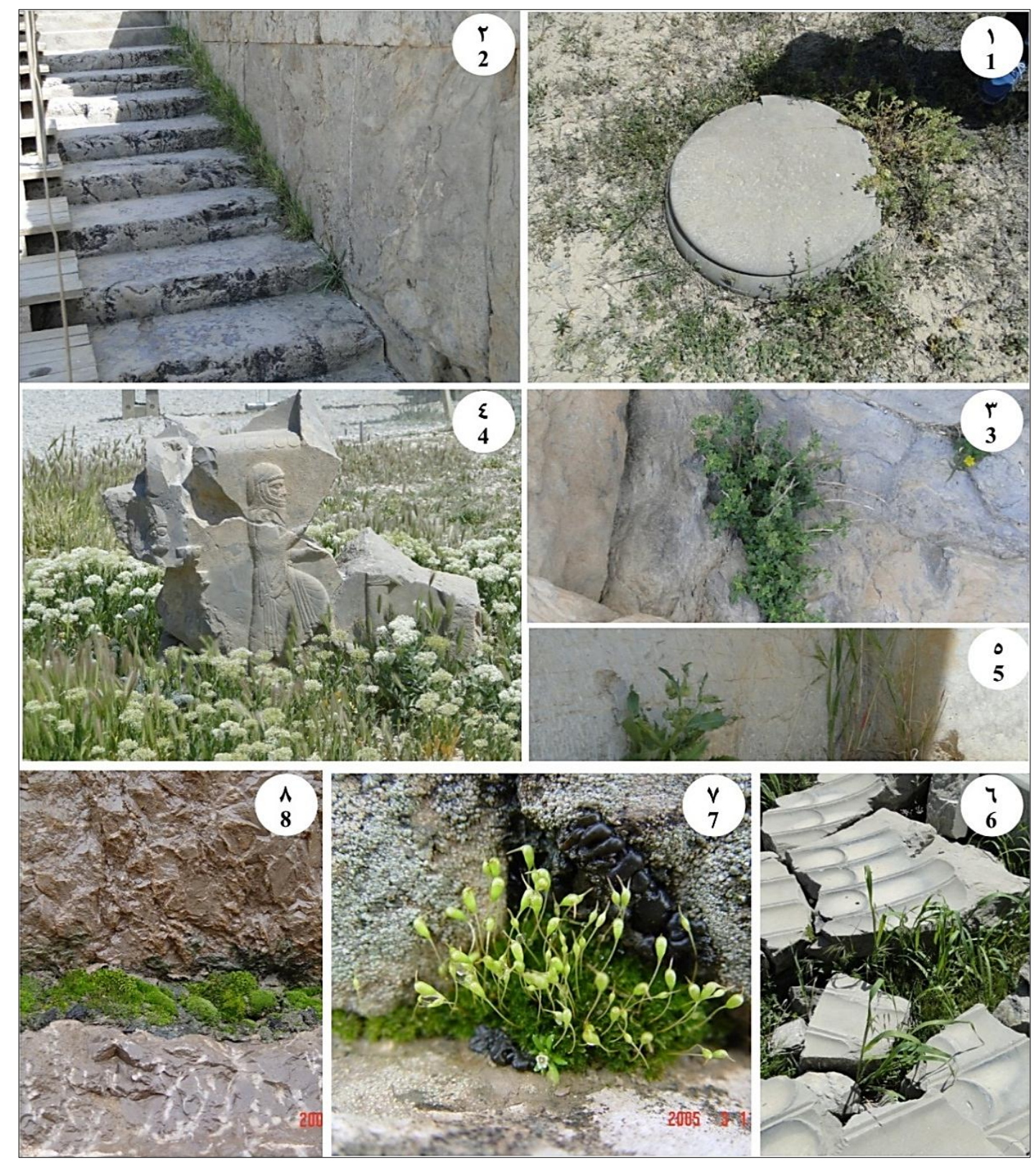

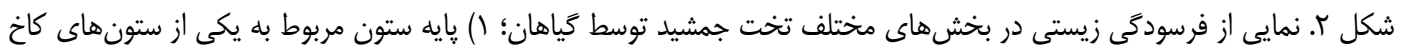

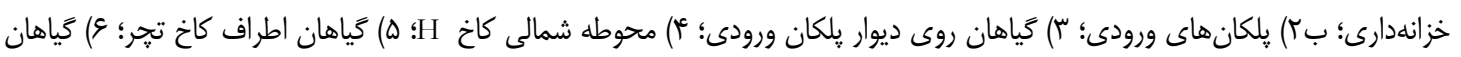

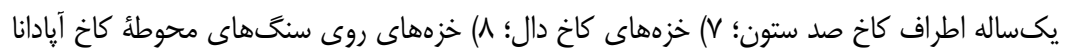

Fig 2: The View of biodegradation in different parts of Persepolis by plants. 1) The base of the column in the Treasury Palace; 2) The entrance stairs; 3) The plants on the wall of the entrance stairs; 4) The northern area of the palace; H; 5) The plants around Thatcher Palace; 6) Annual plants around the palace of Hundred Columns; 7) Moss of Dal Palace; 8) Moss on the rocks of Apadana Palace. 
بنابر اين سلولهاى آنها رنخى ديده مسىشـوند. بــرخلاف

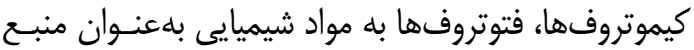
انرزى احتياج ندارند. اينيك مزيت متابوليكى مؤثر اسـت

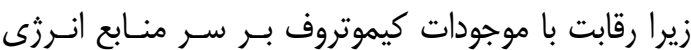

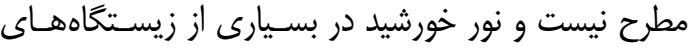

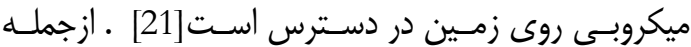

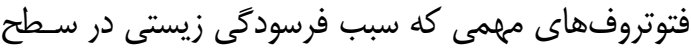

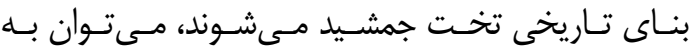
سيانوباكترها، جلبكها و خزمها تها اشاره كرد.

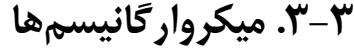

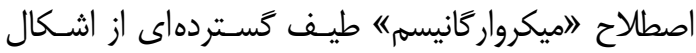
زندگىى، ازجمله بـاكترىهـا، سـيانوباكترىهـا، جلبـكـهـا،

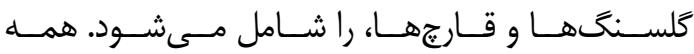

ميكروار كانيسمهاى ذكرشده، خاصيت اكولوزيكى مختلفى إنى

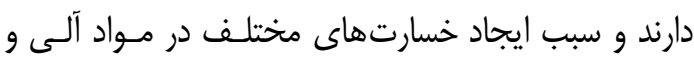

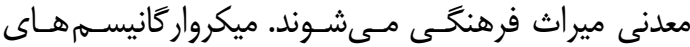

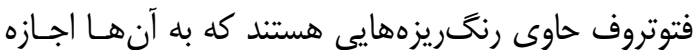

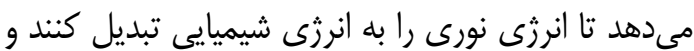
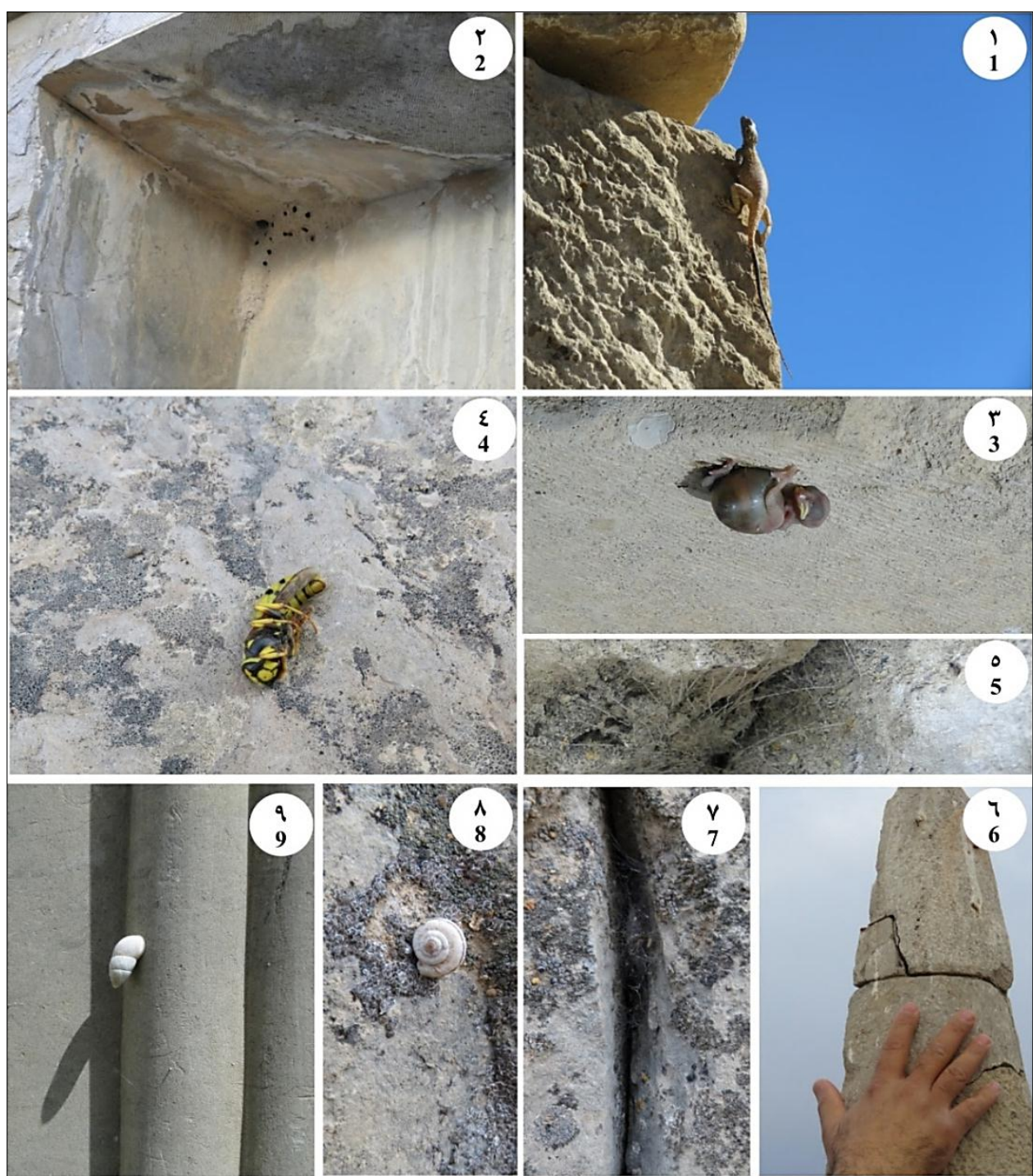

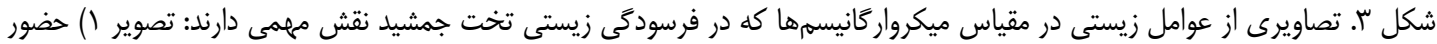

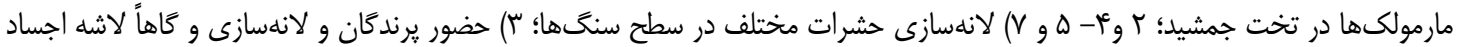

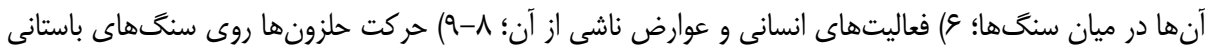

Fig 3: Images of macro-scale biological factors that play an important role in the biodeterioration of Persepolis: 1) The presence of lizards in Persepolis; 2, 4-5,7) The nesting of various insects on the surface of rocks; 3) The presence of birds and their nesting activites among the rocks; 6) Human activities and their consequences; 8-9) The movement of snails on the historic rock surfaces. 
دماى بالا هستند، جداسازى باكترىها با رنغَدانـهــاى

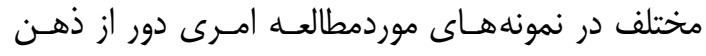

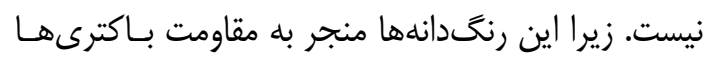

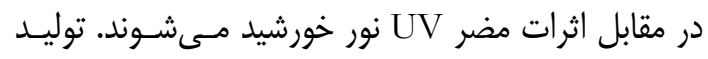

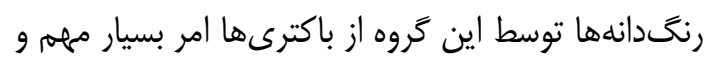

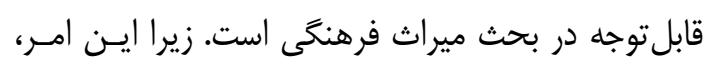

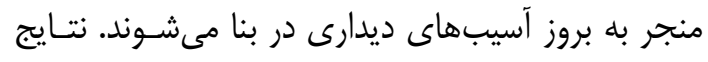

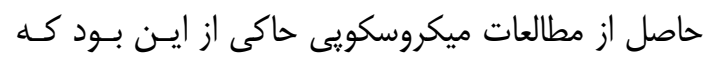
بيشتر گروه باكترىهاى جداسازى شده كو مسى و و باسيل

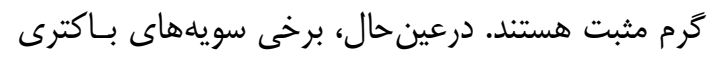

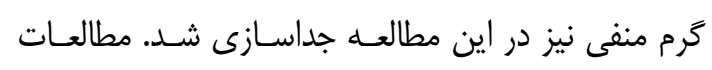

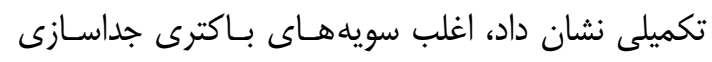

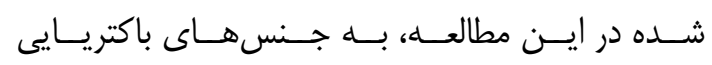

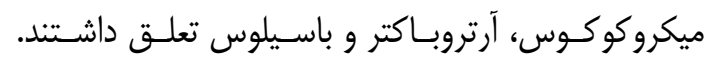

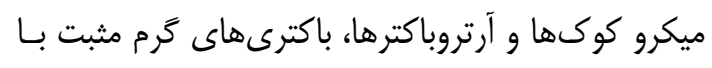

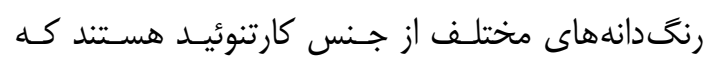

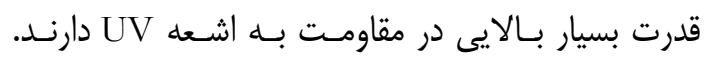

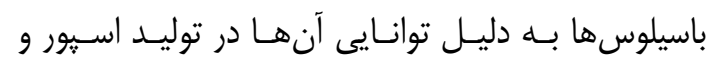

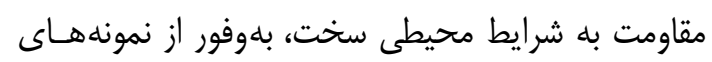
مختلف محيطى جداسازى مى شوند.

\section{س-ه. سيانوباكترىها}

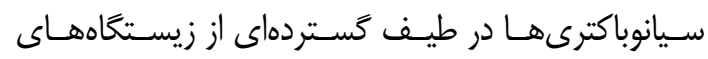

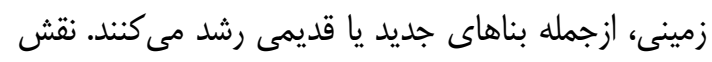

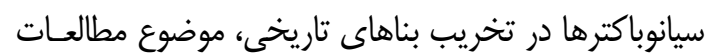

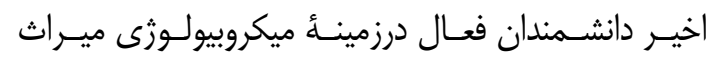

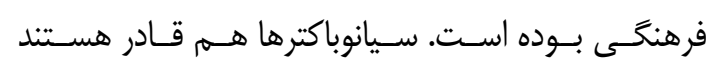

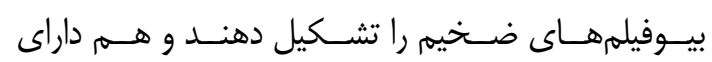

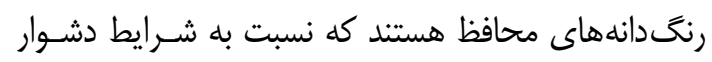

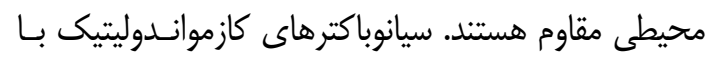

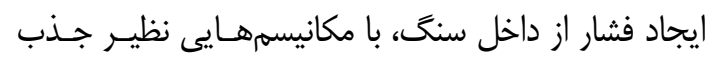

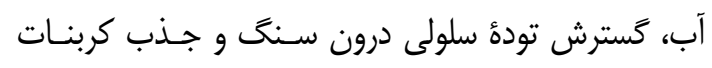

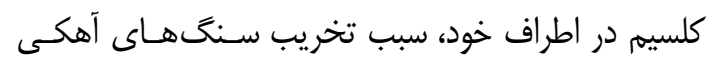

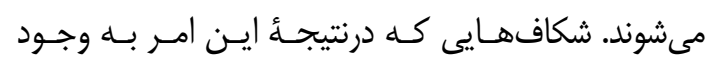

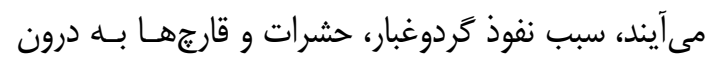

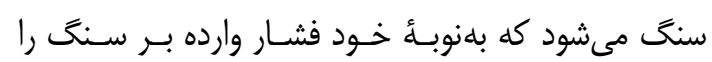

\section{س-ع. باكترىها}

ميكرواركانيسمها نقشى مهرم و كليدى، در زيستـاهـاهـاى

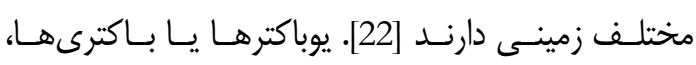
اركانيسمهايى با توانايى عملكردهاى متابوليك بارئ بالا هستند

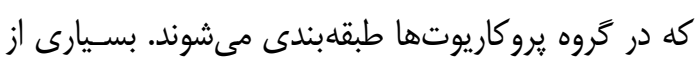

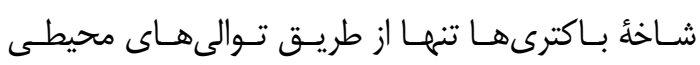

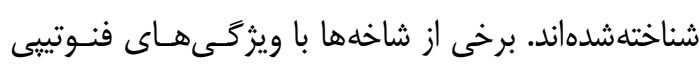

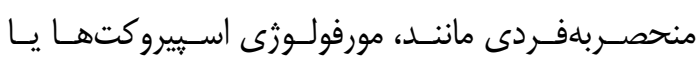
فيزيولوزى خاص سيانوباكترها، شناخته شدهاند، امـا اغلـب مئب

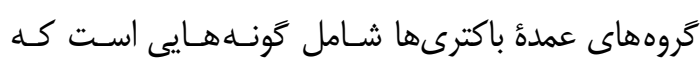

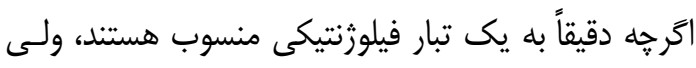
تشابهات فنوتييى برجستهاى ندارند [23]. اين حقيقت كـهـ دئه

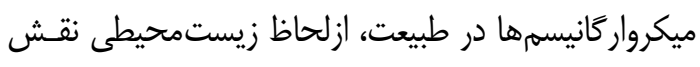

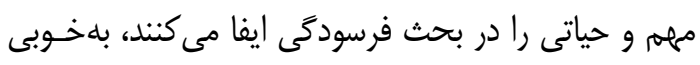

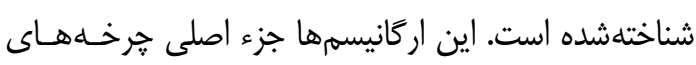

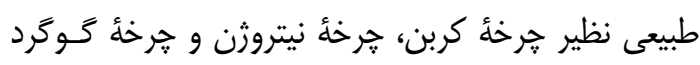

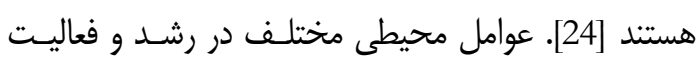

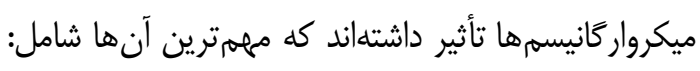

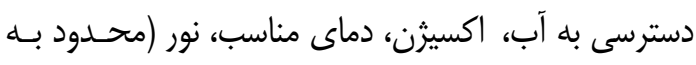

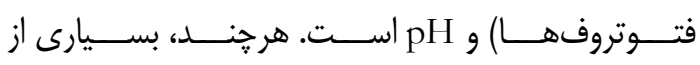

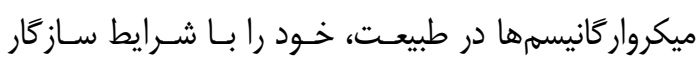

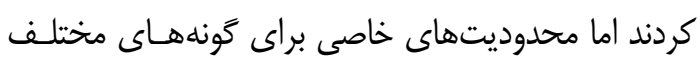

$$
\text { مطرح است. }
$$

باكترىها قـادر بـه كلـونيزه شـدن در سـطح آثـار

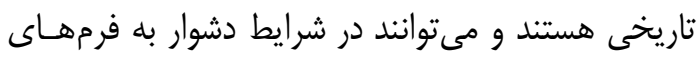

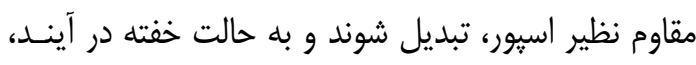
در اين شرايط باكترى ازلحاظ متابوليى غيرفعال است و

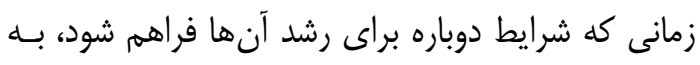

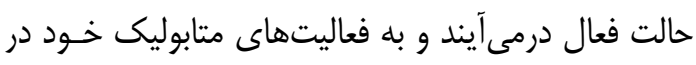

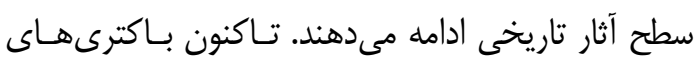

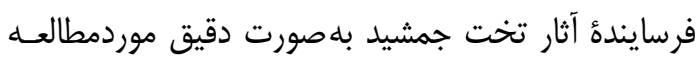
قرار نخرفته است.

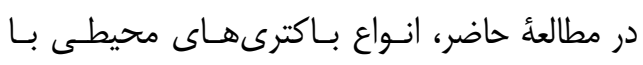
كلونىهاى صورتى، كرم، سفيد، نارنجى و زرد با اندازه و

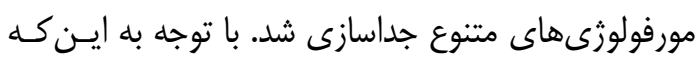

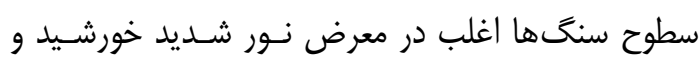




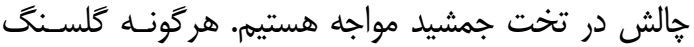
زدايى در منطقه بلدون در نظر گـرفتن جمعيـت باكتريـايى

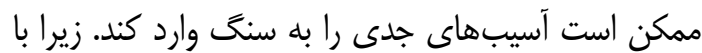

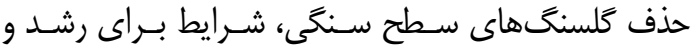
گسترش جمعيت سيانوباكترها و باكترىهاى اندوليتيك يـا بلاصطلاح درون سنگىى، فراهم مىشود. باكترىهاى مولد ييخمنت يا رنخــانههاى صورتى نيـز يكـى از مهـمتـرين

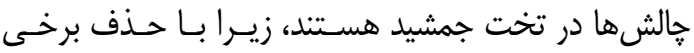

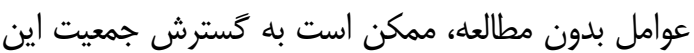
باكترىها دامن زده شود. بنابراين، يِيش از هر گونـه اقـدام

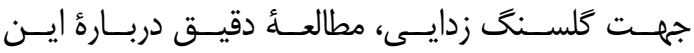

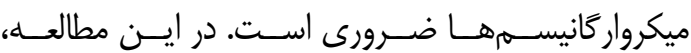

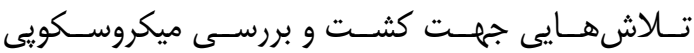
اين گونهها انجامشده كه براى تأييد گونأه دقيق، مطالعـات بعدى در سطح مولكولى نياز است.
تشديد مى كند. سيانوباكترها به علت داشتن رنخـريـزههـا، تغييرات رنكى را در سطح سنگ ايجاد مى كنند. در تخت جمشيد يس از بارش باران در بخشهايى از

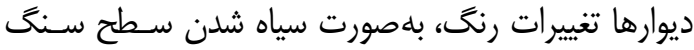
مشاهده مىشود كه يكى از علل اصلى اين يديده، حضــور

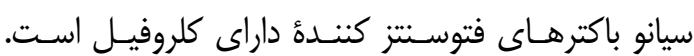
سيانوباكترها جمعيت منحصربdفردى از باكترىها هسـتند

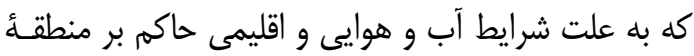

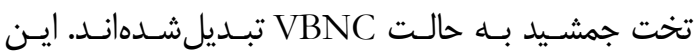
استراتزى در باكترىها به حالتى كفته مىشود كه بـاكترى

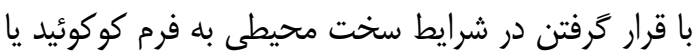

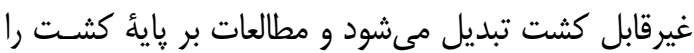
براى محققان دشوار مى كند. نمونههايى از كوكوئيد شـدن

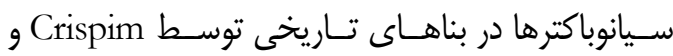
همكاران توصيفشده است [25]. متأسفانه ما نيـز بـا ايـن
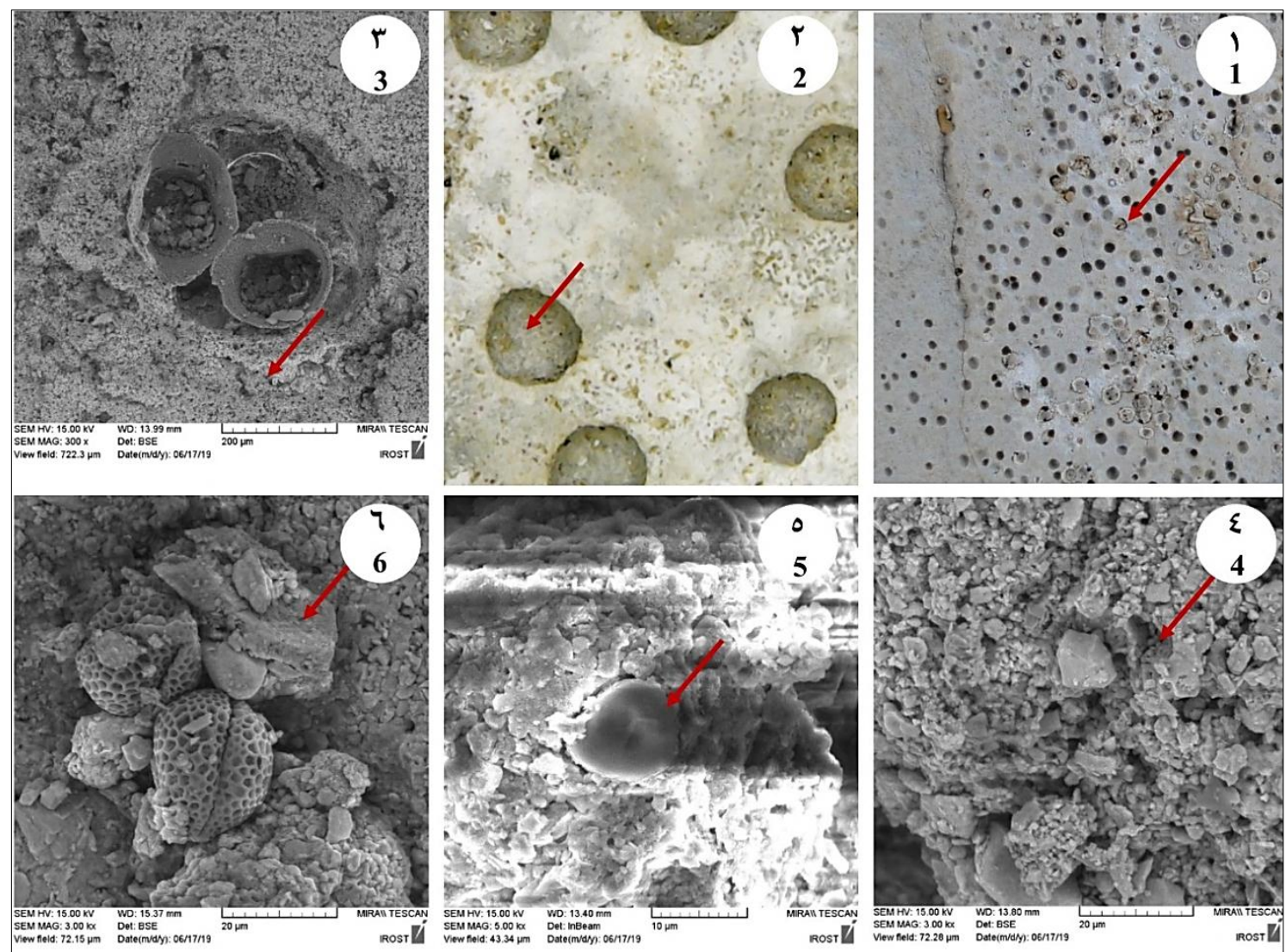

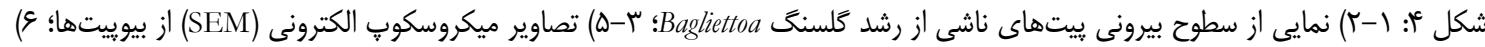

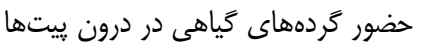

Fig. 4: 1-2) View of the outer surfaces of biopits from the growth of Bagliettoa lichen; 3-5) The Scanning Electron Microscopy (SEM) images of biopits; 6) The presence of plant pollen inside the biopits. 
در ميـراث جهـانى تخـت جمشـيد نمونسهـهـايى از

قارجهاى مرستماتيك ميكروسكويى و مخمرى سياه ديده

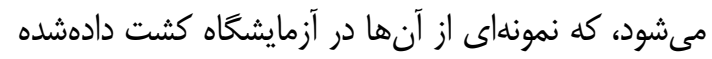

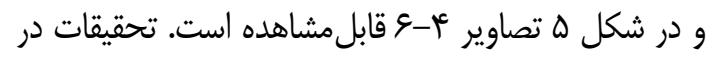
اين خصوص ادامه دارد و جنسها و كَونههاى مختلفى از

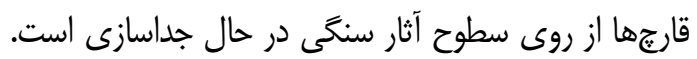

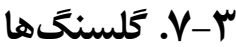

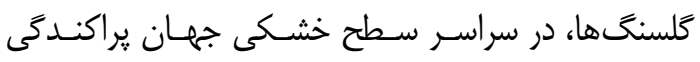
دارند، بلمطورى كه حدود هشت درصد سطح خشكى هـا، بـا
" - (-7. قارجها

قارجها موجودات هتروتروفيك يوكاريوتى هستـتد كـه بـا

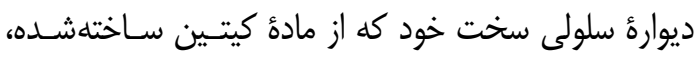
شناخته مىشوند. آنها به فرمانروايى مستقل قارجها تعلق كانق

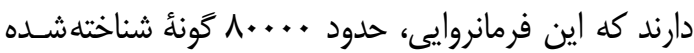

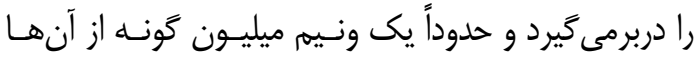

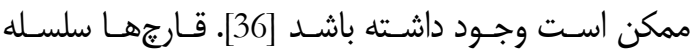

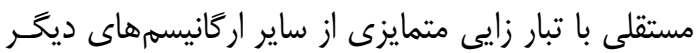

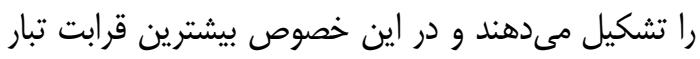

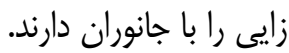
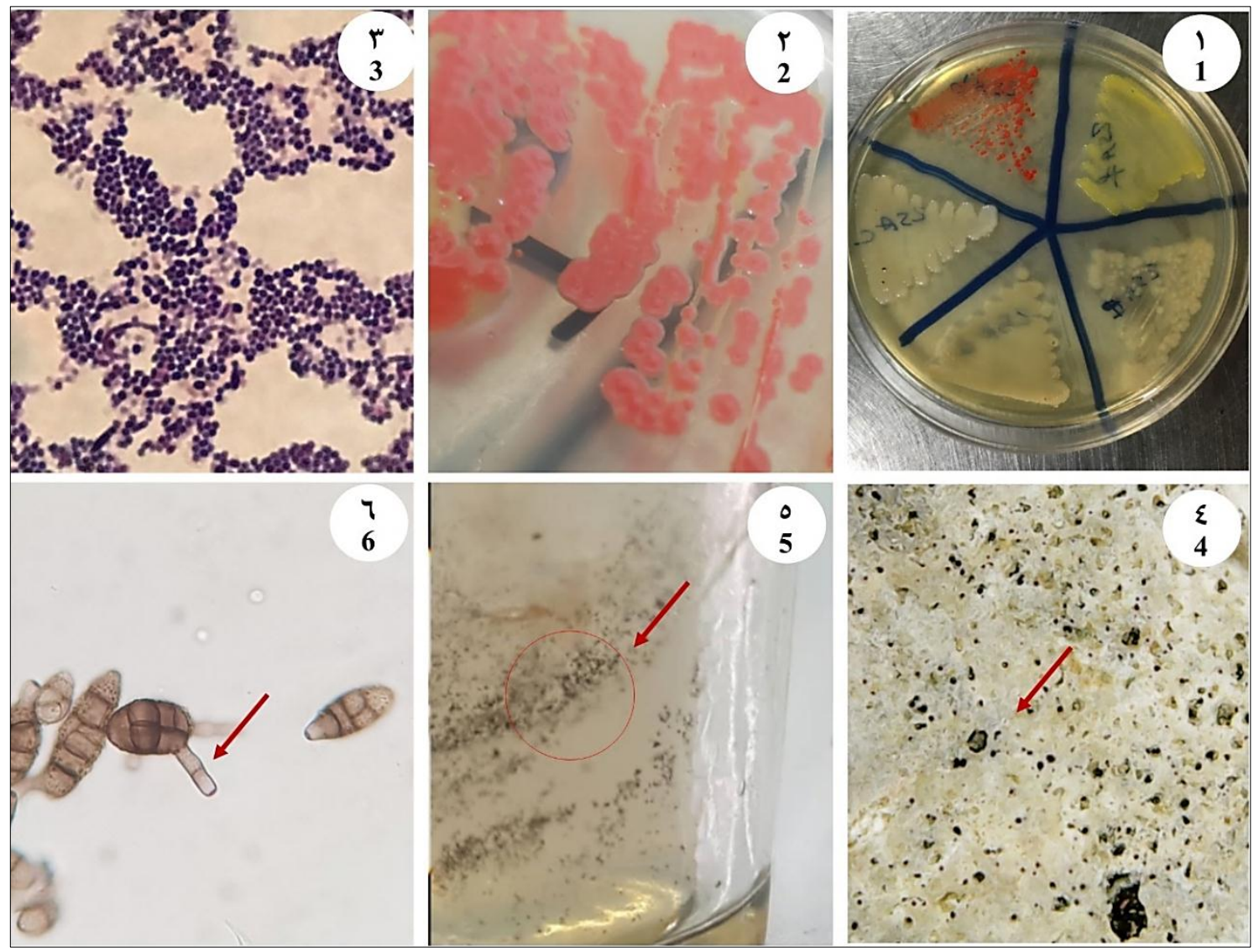

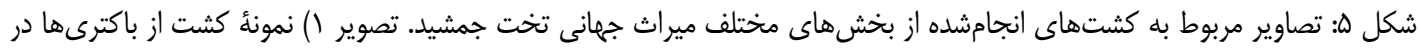

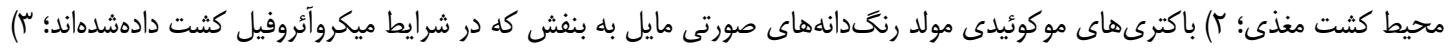

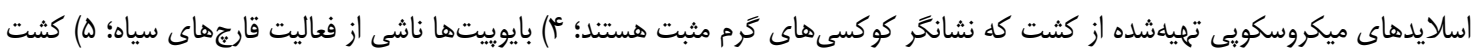

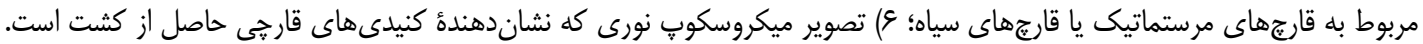

Fig 5: Images related to cultivations carried out in different parts of Persepolis World Heritage. 1) Culture sample of bacteria in nutrient culture medium;2) Mucoid bacteria producing pinkish-purple pigments cultured under microaerophilic conditions; 3) Microscopic slides prepared from imaginary culture showing gram-positive cocci. 4) Biopits Due to the activity of black fungi; 5) The culture related to meristematic fungi or black fungi; 6) Light microscope image showing fungal conidia from culture. 


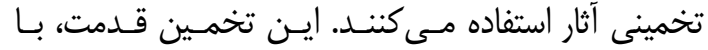

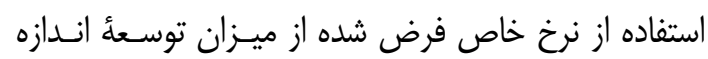

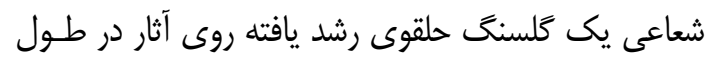

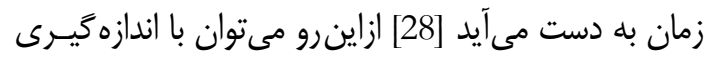

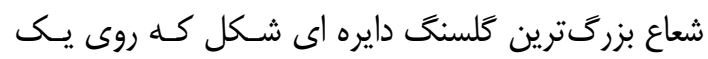

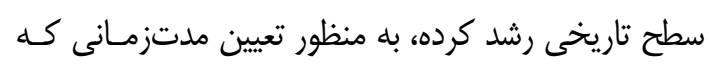

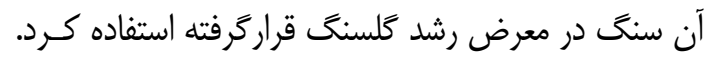

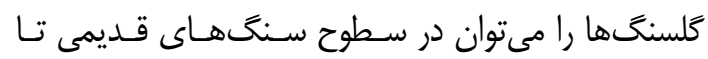

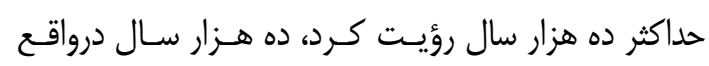

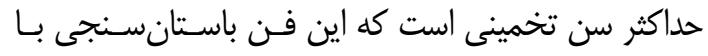

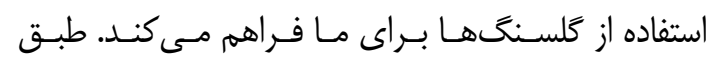

بر آوردها دقت اين روش با • (\% خطا همراه است [36].

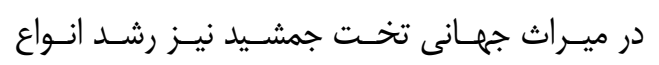

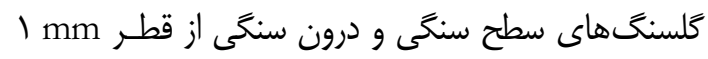

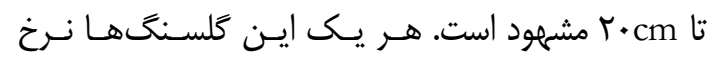

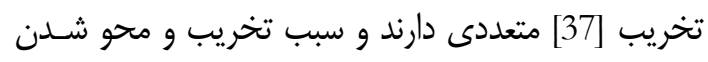

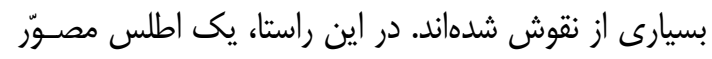

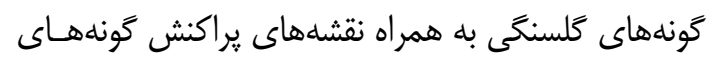

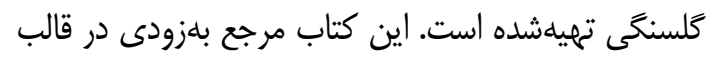

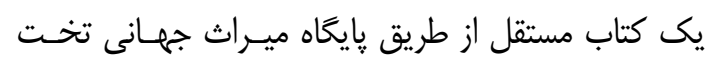

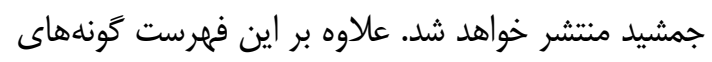

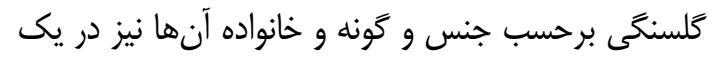

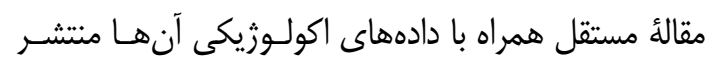

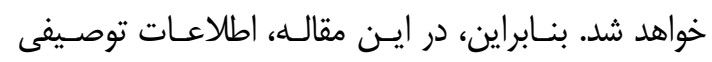
كلسنگ خاى ميراث جهانى تخت جمشيد ارائه نمىشود.

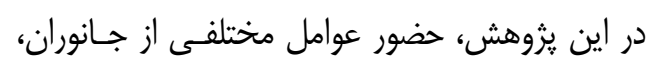

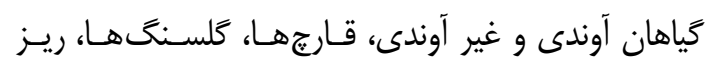

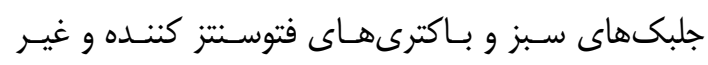

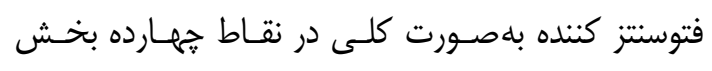

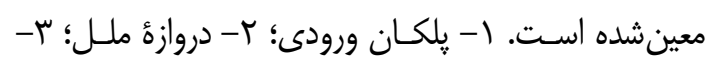

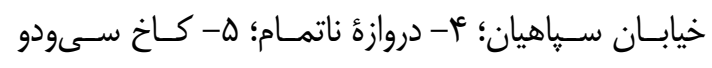

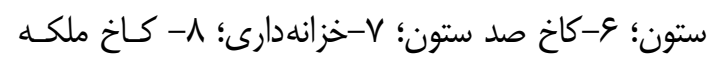

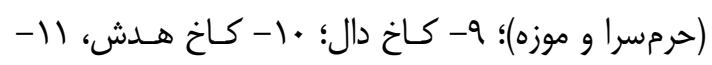

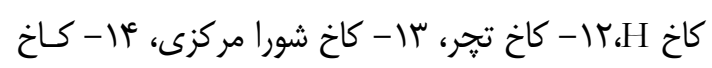

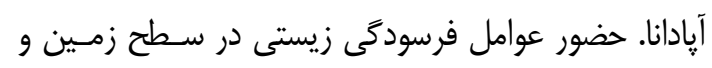

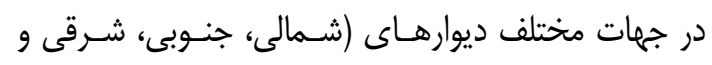

كلسنَ يوشيده شدهاند [26]. شواهد موجود در سنگَوارهها و مطالعات فيلوزنى نشان مىدهند كه قديمىترين فسـيل

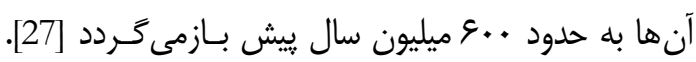

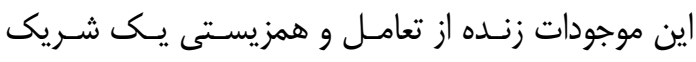

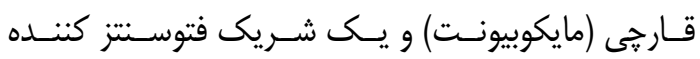

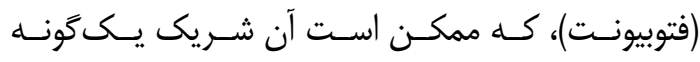

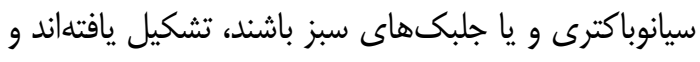

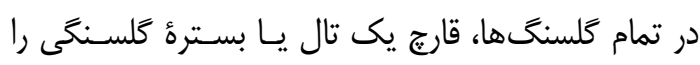

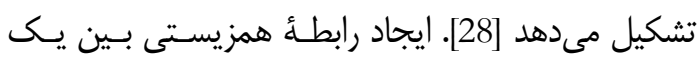

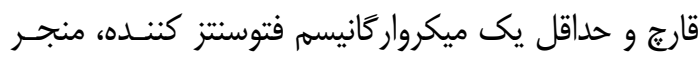

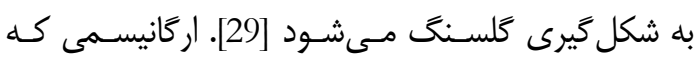
تفاوتهاى قابل توجهى با شركاى تشكيل دهندهاش دارد و و

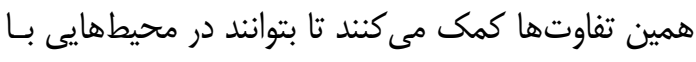

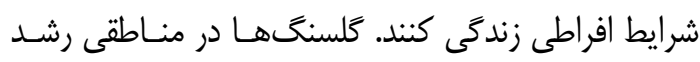

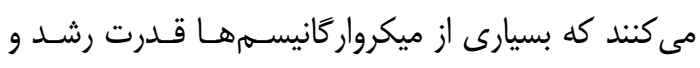

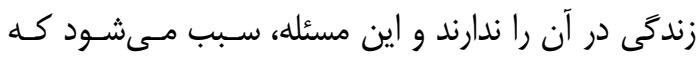

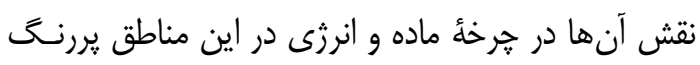

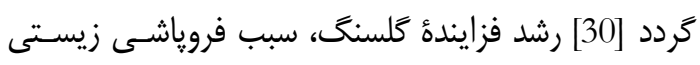

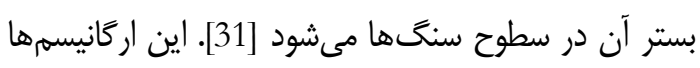

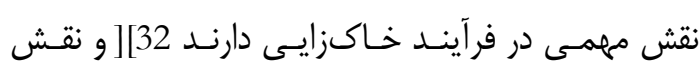

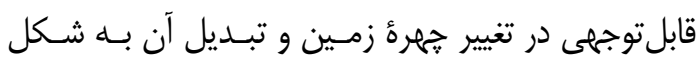

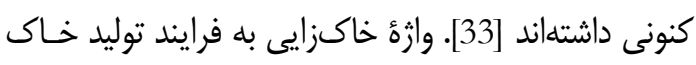

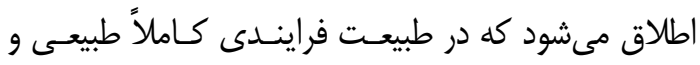

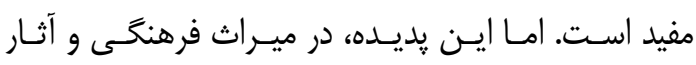
تاريخى سنكى امرى نامطلوب است و باعث تخريسب آثـار

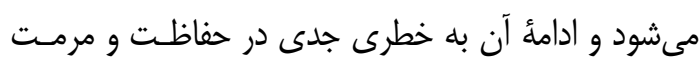

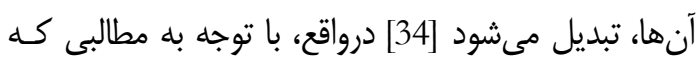

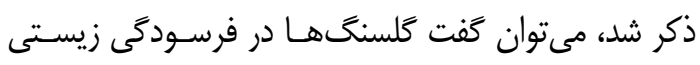

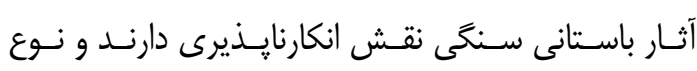

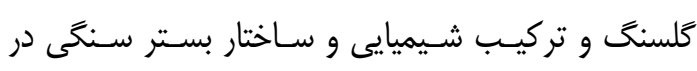
ميزان فرسايش اين آثار تأثير بسزايى دارد [8,35]

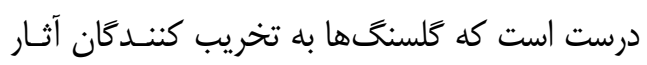

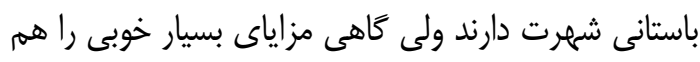

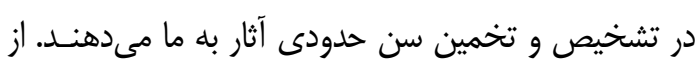

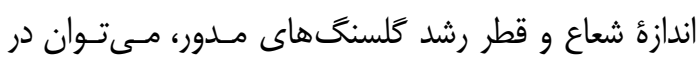

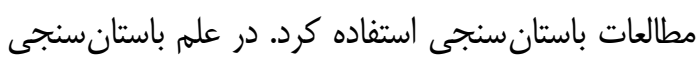

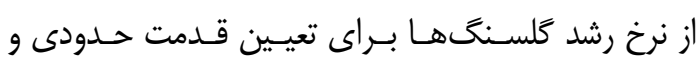




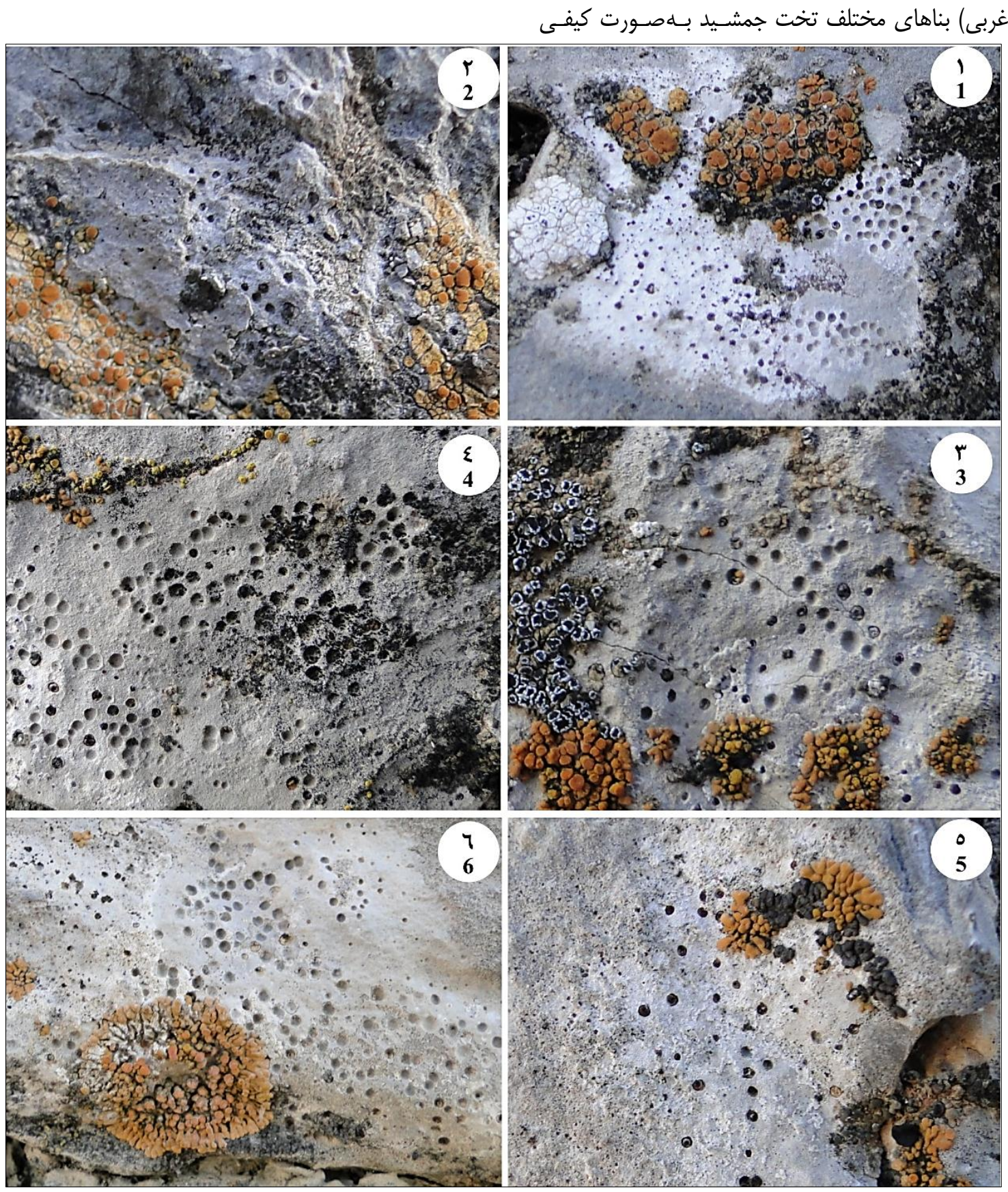

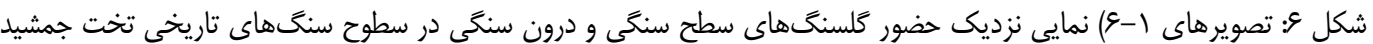

Fig 6: Pictuers 1-6) A close-up epilithic and endolithic lichens on the surface of the historic rock surfaces of Persepolis.

عوامل دخيل در فرسودگى زيستى در رابطـهـ بـا نيازهـاى

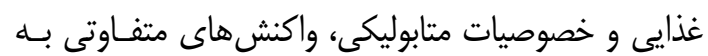

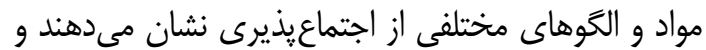

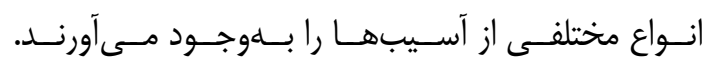

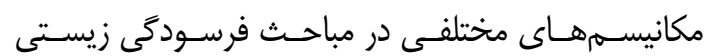
بسترهاى سنكى مطرح مىشوند كـه شـامل: فراينـدهاى

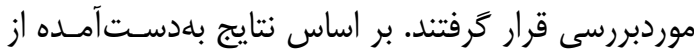

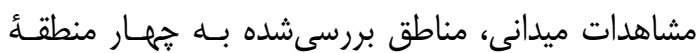

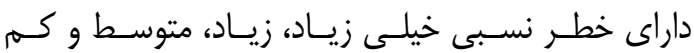
درجهبندى شدند.

ع. بحث

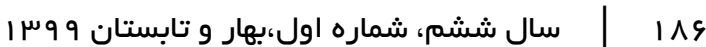




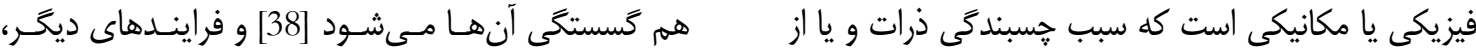

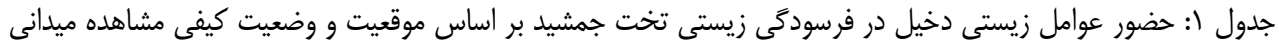

Table1: the presence of biological agants that are involved in the biodeteroration of Persepolis world heritage site, based on the position and qualitative field observations.

\begin{tabular}{|c|c|c|c|c|c|c|c|}
\hline \multicolumn{4}{|c|}{ خطر نسبى تأثير عوامل } & \multirow{2}{*}{ 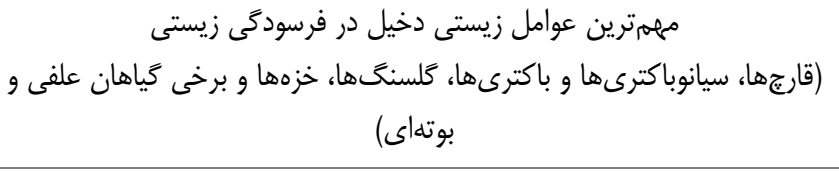 } & \multirow{2}{*}{. } & \multirow{2}{*}{$\begin{array}{l}\text { के } \\
\text { :के: } \\
\text { :र: }\end{array}$} & \multirow[b]{2}{*}{3} \\
\hline$y_{2}$ & $\begin{array}{l}3 \\
3 \\
3\end{array}$ & 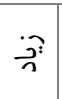 & ij & & & & \\
\hline & & $\checkmark$ & & سيانوباكترىها و باكترىها & | روباز & جنوبى & \\
\hline & & & $\checkmark$ & كلسنگ & روباز & 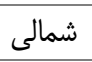 & \\
\hline & $\checkmark$ & & & سيانوباكترىها و باكترىها، كلسنخها & | روباز & 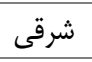 & \\
\hline \multirow[t]{4}{*}{$\checkmark$} & & & & كلسنگها، سيانوباكترىها و باكترى & روباز & 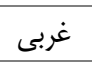 & \\
\hline & $\checkmark$ & & & 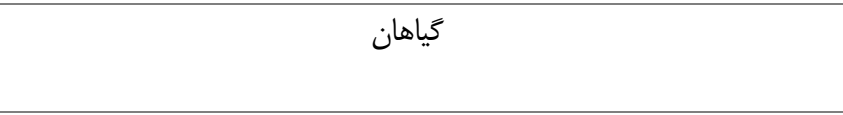 & | روباز & زمين & \\
\hline & $\checkmark$ & & & قارجها، سيانوباكترىها و باكترىها & | روباز & 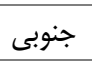 & \\
\hline & & & $\checkmark$ & قارجها، سيانوباكترى ها و باكترىها، كلسنخَها، خزهها & | روباز & 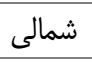 & \\
\hline \multirow[t]{2}{*}{$\checkmark$} & & & & باكترىها & 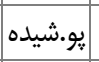 & 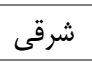 & 2." \\
\hline & & $\checkmark$ & & سيانوباكترى ها و باكترىها & روباز & 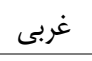 & \\
\hline \multirow[t]{6}{*}{$\checkmark$} & & & & كياهان & روباز & زميح & \\
\hline & $\checkmark$ & & & قارجها، سيانوباكترى ها و باكترىها، كلسنگ ها، كياهان، خزهها & روباز & 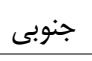 & \\
\hline & & & $\checkmark$ & قارجها، سيانوباكترى ها و باكترى ها، كلسنگ ها، كياه، خزهها & روباز & 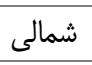 & \\
\hline & & $\checkmark$ & & قارجها، سيانوباكترى ها و باكترىها، ريز جلبكها، كلسنگها، خزهها & روباز & 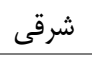 & \\
\hline & $\checkmark$ & & & قارجها، سيانوباكترىها و باكترىها، ريز جلبكها، كلسنگ ها & | روباز & غربى & \\
\hline & $\checkmark$ & & & كياهان علفى & روباز & زمين & \\
\hline$\checkmark$ & & & & قارجها، سيانوباكترى ها و باكترىها، ريز جلبكها & | روباز & 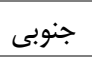 & \\
\hline \multirow[t]{4}{*}{$\checkmark$} & & & & باكترىها & 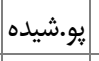 & 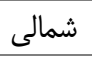 & \\
\hline & $\checkmark$ & & & قارجها، سيانوباكترىها و باكترىها، ريز جلبكها، كلسنحَها & روباز & 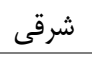 & \\
\hline & $\checkmark$ & & & قارجها، سيانوباكترى ها و باكترى ها، ريز جلبكها & روباز & 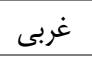 & \\
\hline & $\checkmark$ & & & كَياهان & روباز & زمين & \\
\hline \multirow[t]{5}{*}{$\checkmark$} & & & & قارجها، سيانوباكترىها و باكترىها، ريز جلبكها & روباز & 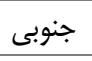 & \\
\hline & & & $\checkmark$ & قارجها، سيانوباكترىها و باكترىها، ريز جلبكها، كلسنگها، خزهها & روباز & 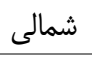 & \\
\hline & $\checkmark$ & & & قارجها، سيانوباكترىها و باكترىها، ريز جلبكها، كلسنخَها & | روباز & 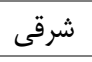 & \\
\hline & $\checkmark$ & & & قارجها، سيانوباكترىها و باكترىها، ريز جلبكها، كلسنگها & روباز & 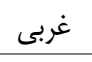 & \\
\hline & & & $\checkmark$ & 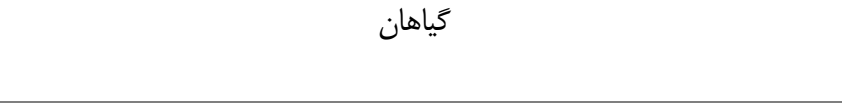 & روباز & زمين & \\
\hline \multirow[t]{2}{*}{$\checkmark$} & & & & قارجها، سيانوباكترىها و باكترى ها، ريز جلبكها & روباز & 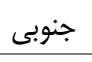 & \\
\hline & $\checkmark$ & & & قارجها، سيانوباكترى ها و باكترى ها، ريز جلبكها، كلسنخها، خزهها & | روباز & 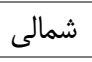 & \\
\hline$\checkmark$ & & & & قارجها، سيانوباكترىها و باكترىها، ريز جلبكها، كلسنگها، & روباز & 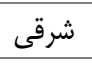 & 贿 \\
\hline \multirow[t]{2}{*}{$\checkmark$} & & & & قارجها، سيانوباكترىها و باكترىها، ريز جلبكها، & روباز & 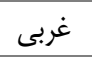 & \\
\hline & & & $\checkmark$ & كَياهان، عوامل انسانى & | روباز & سطح ( - la & \\
\hline
\end{tabular}

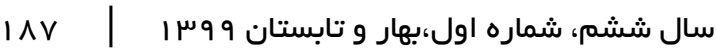




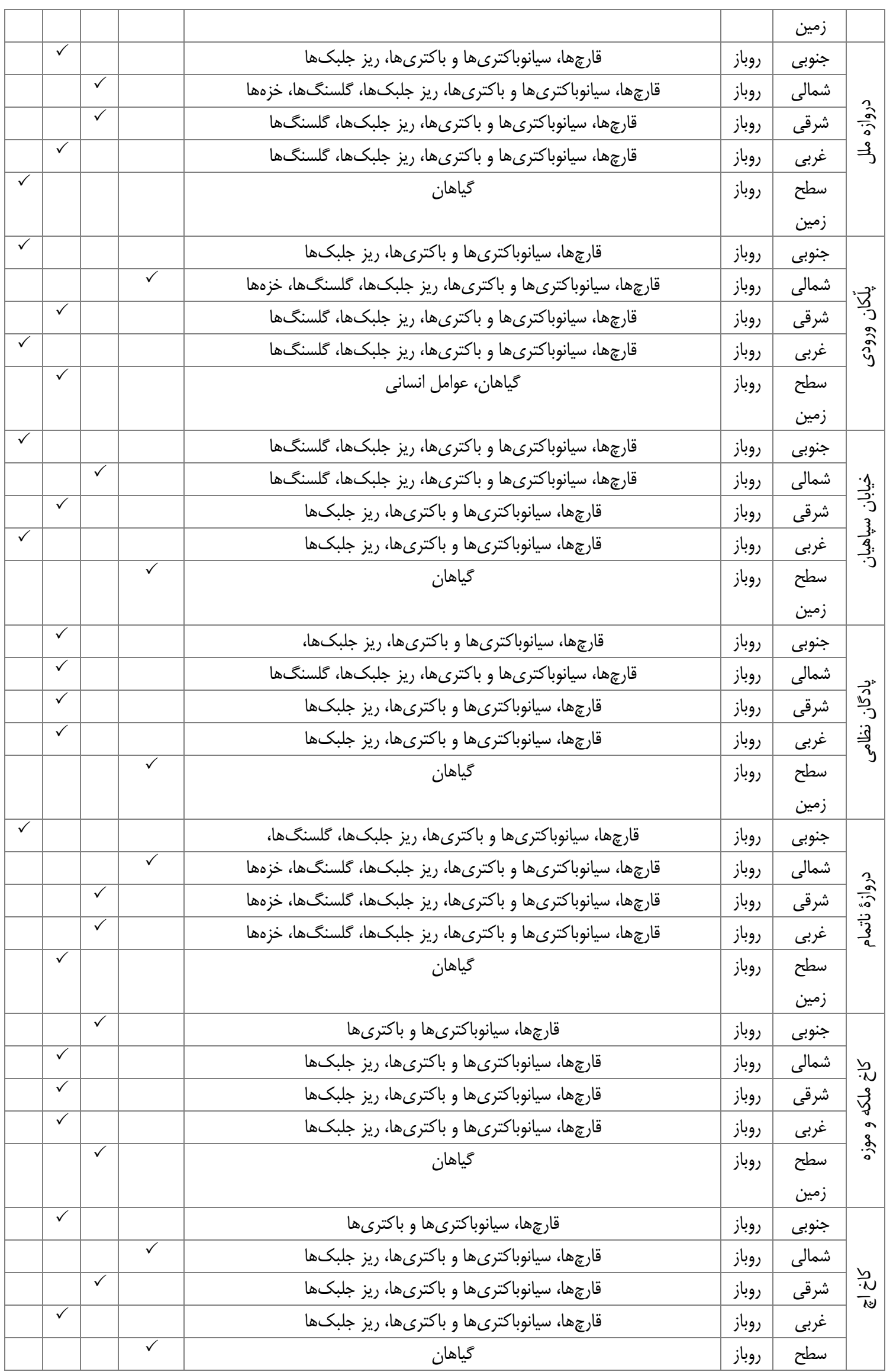




\begin{tabular}{|c|c|c|c|c|c|c|}
\hline & & & & & زمين & \\
\hline & $\checkmark$ & & قارجها، سيانوباكترىها و باكترىها & روباز & جنوبى & \\
\hline & & $\checkmark$ & قارجها، سيانوباكترى ها و باكترىها، ريز جلبكها & 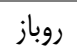 & 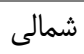 & \\
\hline$\checkmark$ & & & قارجها، سيانوباكترى ها و باكترى ها، ريز جلبكها & روباز & 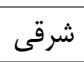 & $\frac{V}{N}$ \\
\hline & $\checkmark$ & & قارجها، سيانوباكترى ها و باكترى ها، ريز جلبكها & 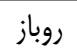 & 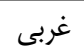 & $\stackrel{n}{\leftrightharpoons}$ \\
\hline & $\checkmark$ & & كياهان & 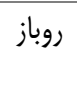 & زمين & \\
\hline
\end{tabular}

مىتوانند از مواد آلـى موجـود در طبيعت دريافـت كنتـــ.

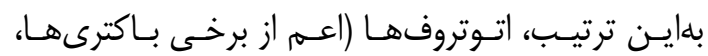

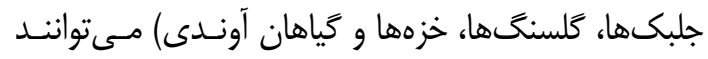

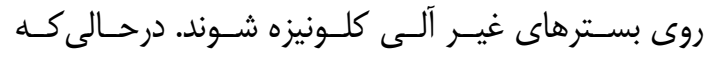

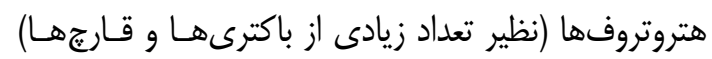

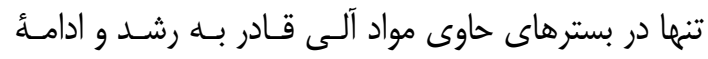

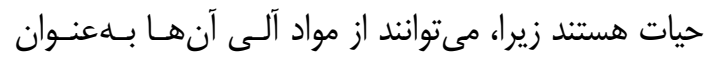
منبع انرزى استفاده كنند.

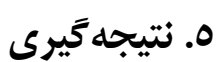

مجموعأ تاريخى ميراث جهـانى تخـت جمشـيد يكسى از

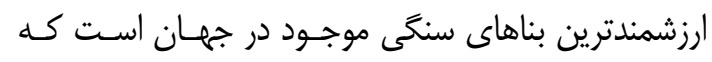

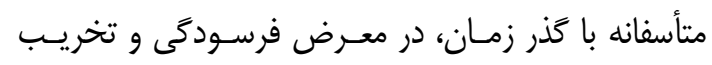
عوامل مختلف محيطى زنده و غيرزنده قرارگَرفته است. از

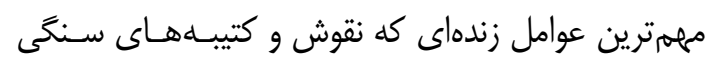

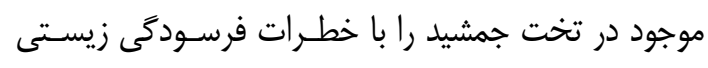

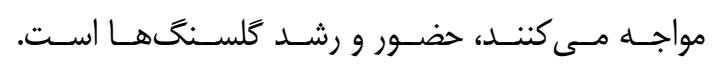
بررسى هاى ميدانى نشان مىدهند كه بيش از بيست كونئه كلسنكى تنها درروى كتيبههاى خط مينى كـاخ

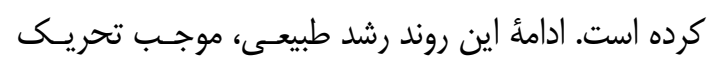

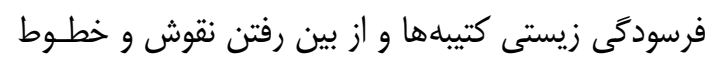
ميخى شدهاند.

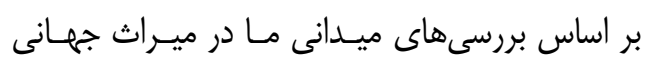

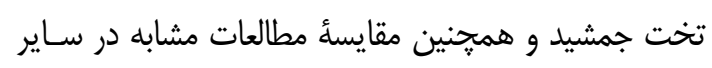

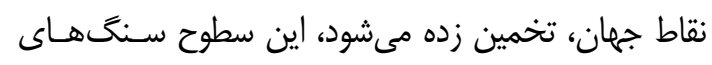

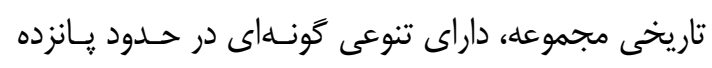

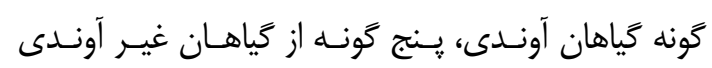
(خزمها) اغلب در سطح يا شكاف سنگَها، بين شانزده تـان

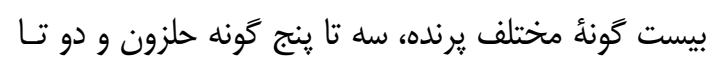

شامل فر آيندهاى شيميايى است كه بــنوبــــ خـود، سـبب

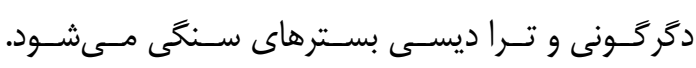

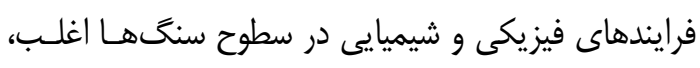

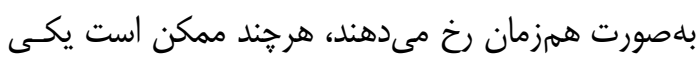

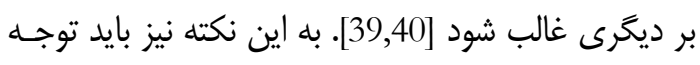

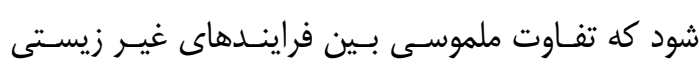

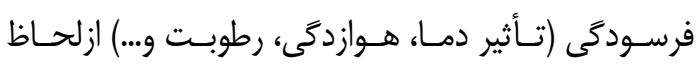

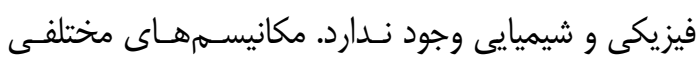

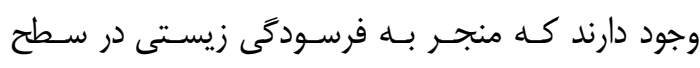

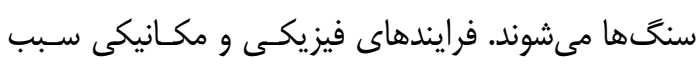

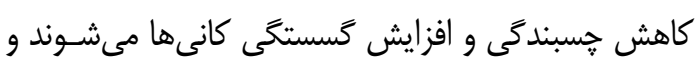

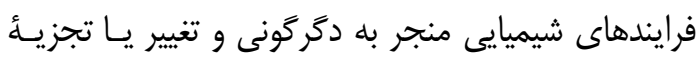

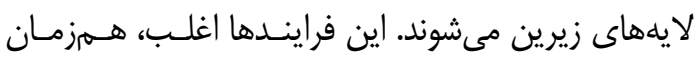

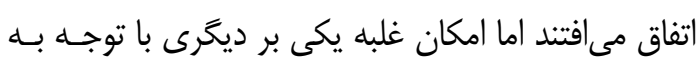

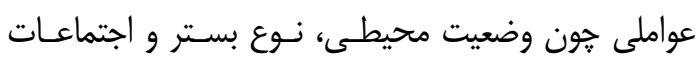

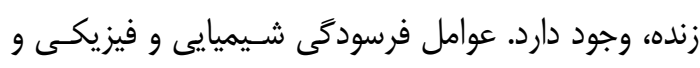

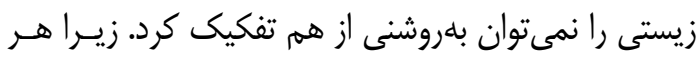

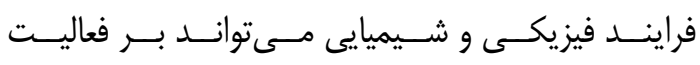

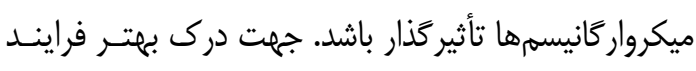
فرسودگى زيستى بايد در درجهُ اول به اين نكته اشاره كرد

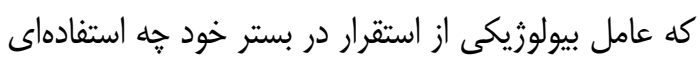

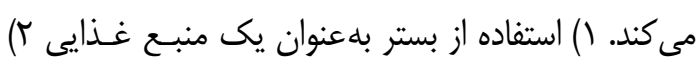

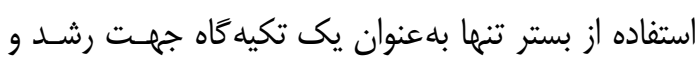

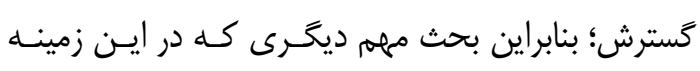

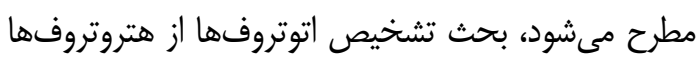

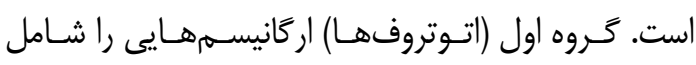

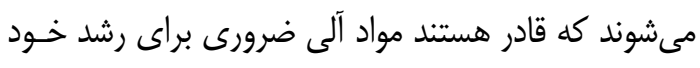

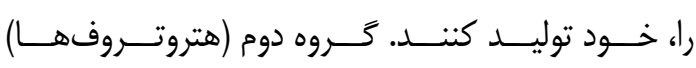

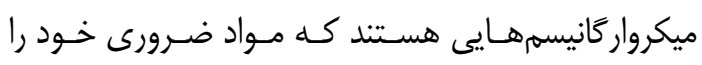




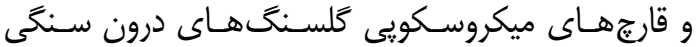
دخيل در فرسودىى زيستى تخـت جمشـيد نقـش داشـته

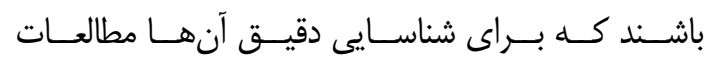
متازنوميكسى نياز است. بر اساس آخرين اطلاعات جمع آورى شده توسط تسيم

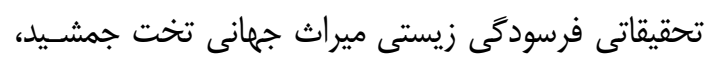

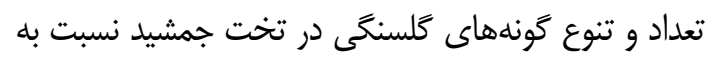

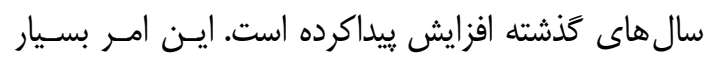

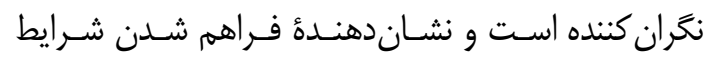

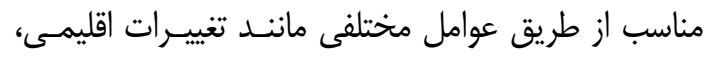

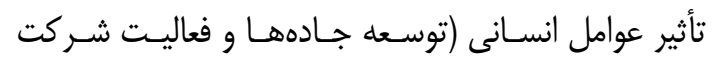

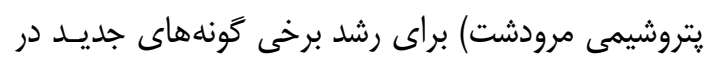

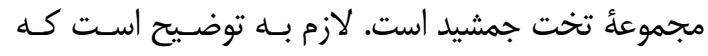

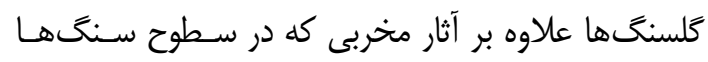

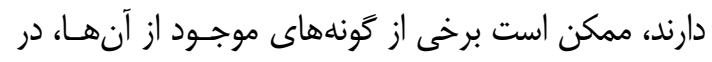

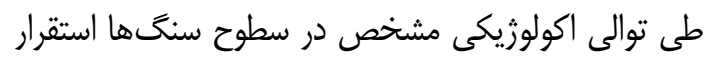

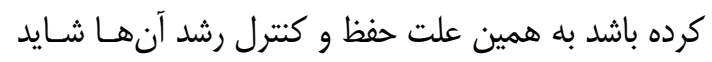

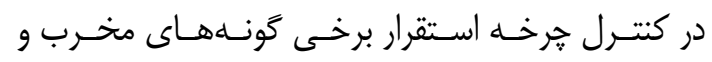
فرصتطلب تأثير داشته باشند.

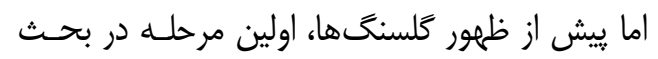

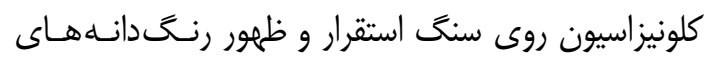

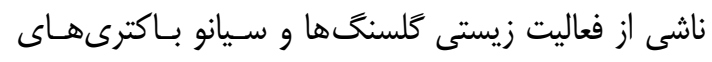

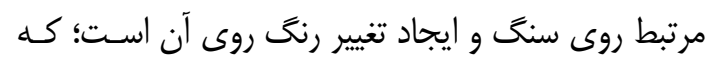
علت اصلى آن بيشتر سيانوباكترها فتوسنتز كننده هستـتند.

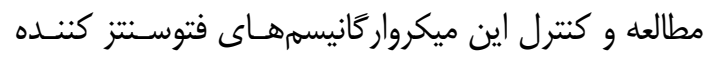

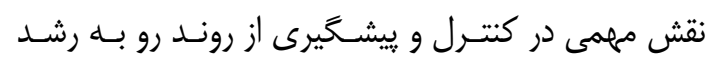

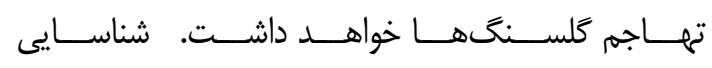

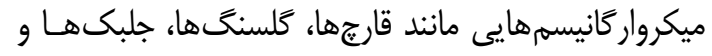

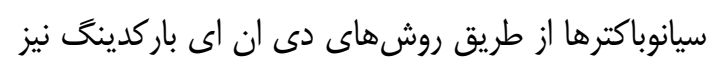

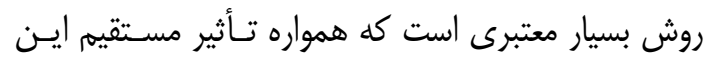

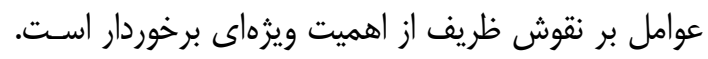
همه اين عوامل منجر به فرسايش تدريجى اين نقـوش و و نورئ محو تدريجى مى هموند.

\section{سياسگزارى}

از مركز مطالعات و همكارى هاى علمى و بينالمللى علـوم و تحقيقات و فناورى براى حمايت از اين تحقيق در قالب ونب
جهار كَونه خزنده، سى الى جهل كَونـه حشـره باشــند. در خصوص حضور ميكرواركانيسمها در سطوح تاريخى تخت كُون

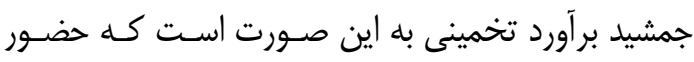

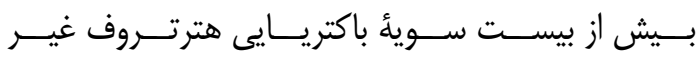

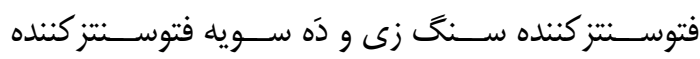

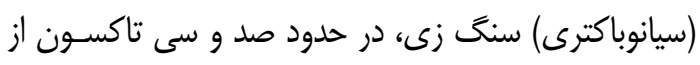

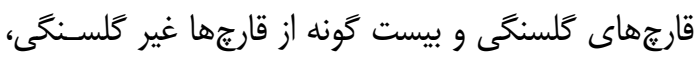
هجده تاكسون جلبك سبز مىتواند در فرسودگى زيسـتى

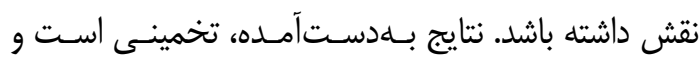

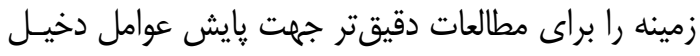
در فرسودگى زيستى فراهم مىآورد كه يكى از ضـروريات اين يايگاه ميراث جهانى است.

\section{ييشنهادها و مسير ييش رو}

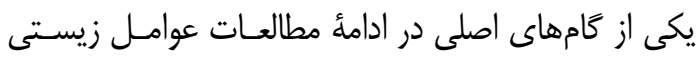

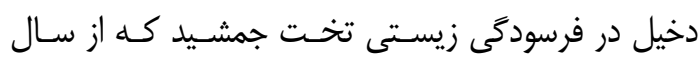

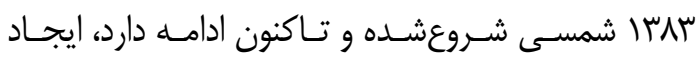

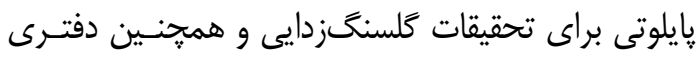

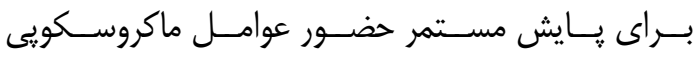

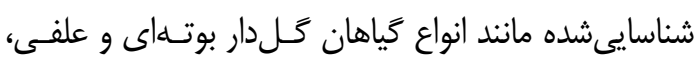

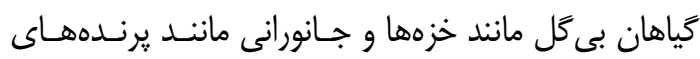

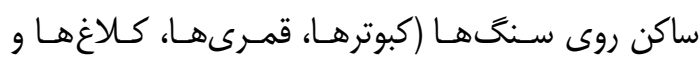

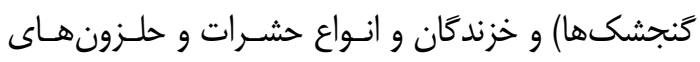

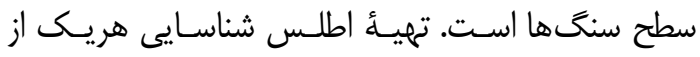
عوامل دخيل در فرسودگى زيستى مى تواند در بيشبرد ايدهُ

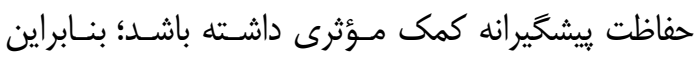

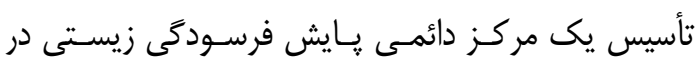

$$
\text { تخت جمشيد يك ضرورت است. }
$$

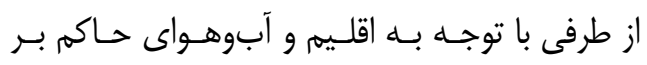

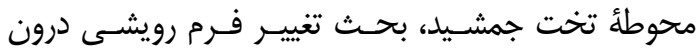

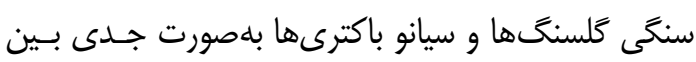

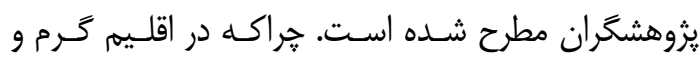

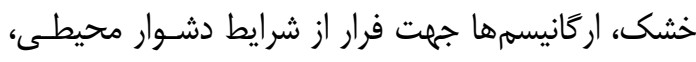
به بخش هاى داخلى سنگ، نفوذ مى كنند و آسيبى كه بـ بـهـ

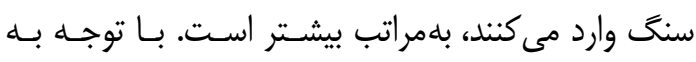

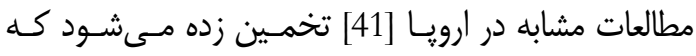

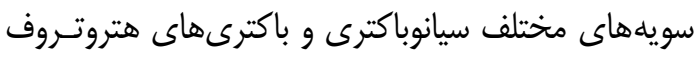

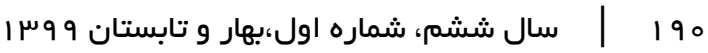




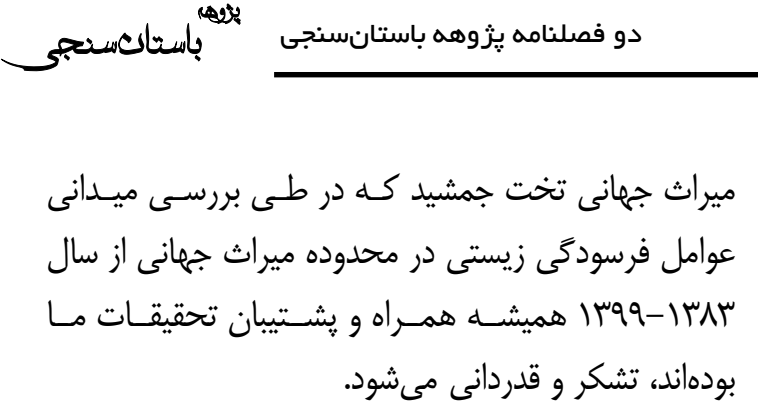

\section{References}

[1] Piervittori R, Salvadori O, Seaward MRD. Lichens and Monuments. In: St.Clair L, Seaward M, editors. Biodeterioration of Stone Surfaces Lichens and Biofilms as Weathering Agents of Rocks and Cultural Heritage. Dordrecht: Springer Netherlands; 2004. p. 241-82.

[2] Pangallo D, Bučková M, Kraková L, Puškárová A, Šaková N, Grivalský T, et al. Biodeterioration of epoxy resin: A microbial survey through cultureindependent and culture-dependent approaches. Environ Microbiol. 2015;17(2):462-79.

[3] Ariño X, Saiz-Jimenez C. Biological diversity and cultural heritage. Aerobiologia (Bologna). 1996;12(1):279_ 82.

[4] Ríos ADL, Cámara B, Ángeles M, Rico VJ, Galván V, Ascaso C, et al. Deteriorating effects of lichen and microbial colonization of carbonate building rocks in the Romanesque churches of Segovia (Spain). Sci Total Environ. 2009;407(3):1123-34.

[5] St.Clair L, Seaward M, editors. Biodeterioration of Stone Surfaces: Lichens and Biofilms as Weathering Agents of Rocks and Cultural Heritage. Dordrecht: Springer Netherlands; 2004. $292 \mathrm{p}$.

[6] Scheerer S, Ortega-Morales O, Gaylarde C. Microbial Deterioration of Stone Monuments-An Updated Overview. In: Laskin AI, Sariaslani S, Gadd GM, editors. Advances in Applied Microbiology. 2009. p. 97-139.

[7] Caneva G, Nugari M, Salvadori O, editors. Plant biology for cultural heritage: biodeterioration and conservation. 1st ed. Los Ángeles, California, USA: Getty Conservation Institute; 2008. 400 p.

[8] Cutler N, Viles H. Eukaryotic Microorganisms and Stone Biodeterioration. Geomicrobiol J. 2010

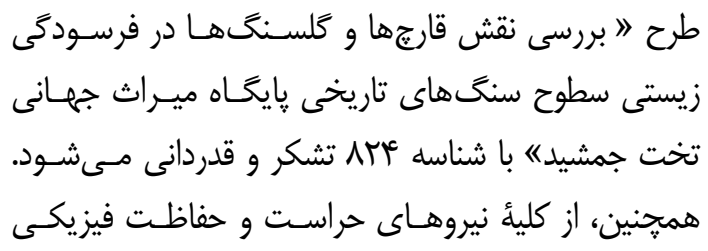

Sep 10;27(6-7):630-46.

[9] Tiano P. Biodeterioration of Stone Monuments a Worldwide Issue. Open Conf Proc J. 2016 Apr 8;7(suppl 1: M3):29-38.

[10] Gorbushina AA. Life on the rocks. Environ Microbiol. 2007;9(7):1613-31.

[11] Fernandes P. Applied microbiology and biotechnology in the conservation of stone cultural heritage materials. Appl Microbiol Biotechnol. 2006;73(2):291-6.

[12] Eaton LK. A History of Architecture: Settings and Rituals Spiro Kostof. J Soc Archit Hist. 2006;47(1):75-6.

[13] De Los Ríos A, Ascaso C. Contributions of in situ microscopy to the current understanding of stone biodeterioration. Int Microbiol. 2005;8(3):181-8.

[14] Sterflinger K, Little B, Pinar G, Pinzari F, de los Rios A, Gu J-D. Future directions and challenges in biodeterioration research on historic materials and cultural properties. Int Biodeterior Biodegradation. 2018;129:10-2.

[15] Shahbazi AS. The authoritative guide to Persepolis. Safiran Publishing Company, Tehran; 2004.

[16] Schmidt EF. Persepolis I: Structures, Reliefs, Inscriptions. 1st ed. Chicago, USA: The University of Chicago Press; 1953. $297 \mathrm{p}$.

[17] Herzfeld E. Prehistoric Persia I: A Neolithic Settlement at Persepolis; Remarkable New Discoveries. 1929.

[18] Schmidt EF. Persepolis II: Contents of the Treasury and Other Discoveries. Chicago, USA: The University of Chicago Press; 1957.

[19] Sterflinger K. Fungi: Their role in deterioration of cultural heritage. Fungal Biol Rev. 2010;24(1-2):47-55.

[20] Biswas J, Sharma K, Harris KK, Rajput Y. Biodeterioration agents: Bacterial and fungal diversity dwelling in or on the prehistoric rock-paints of Kabra-pahad , 
India. Iran J Microbiol. 2013;5(3):309-14.

[21] Bryant DA, Frigaard N-U. Prokaryotic photosynthesis and phototrophy illuminated. Trends Microbiol. 2006;14(11):488-96.

[22] González JM, Sáiz-Jiménez C. Application of molecular nucleic acid-based techniques for the study of microbial communities in monuments and artworks. Int Microbiol. 2005;8(3):189-94.

[23] Hugenholtz P, Goebel BM, Pace NR. Impact of culture-independent studies on the emerging phylogenetic view of bacterial diversity. Vol. 180, Journal of Bacteriology. 1998. p. 4765-74.

[24] Cámara B, De los Ríos A, Urizal M, Álvarez de Buergo M, Varas MJ, Fort R, et al. Characterizing the Microbial Colonization of a Dolostone Quarry: Implications for Stone Biodeterioration and Response to Biocide Treatments. Microb Ecol. 2011;62(2):299-313.

[25] Crispim CA, Gaylarde CC. Cyanobacteria and Biodeterioration of Cultural Heritage: A Review. Microb Ecol. 2005;49(1):1-9.

[26] Chen J, Blume HP, Beyer L. Weathering of rocks induced by lichen colonization A review. Catena. 2000;39(2):121-46.

[27] Grube M, Cardinale M, de Castro JV, Müller H, Berg G. Species-specific structural and functional diversity of bacterial communities in lichen symbioses. ISME J. 2009 Sep 25;3(9):1105-15.

[28] O’Neal MA, Legg NT, Hanson B, Morgan DJ, Rothgeb A. Lichenometric dating of rock surfaces in the northern cascade range, USA. Geogr Ann Ser A Phys Geogr. 2013;95(3):241-8.

[29] Wedin M, Maier S, Fernandez-brime S, Cronholm B, Westberg M, Grube M. Microbiome change by symbiotic invasion in lichens. Environ Microbiol. 2016;18(5):1428-39.

[30] Ariño X, Gomez-Bolea A, Saiz-Jimenez C. Lichens on ancient mortars. Int Biodeterior Biodegradation. 1997;40(24):217-24.

[31] Banfield JF, Barker WW, Welch SA, Taunton A. Biological impact on mineral dissolution: Application of the lichen model to understanding mineral weathering in the rhizosphere. Proc Natl Acad Sci. 1999 Mar 30;96(7):3404-11.

[32] Belnap J, Büdel B, Lange OL. Biological
Soil Crusts: Characteristics and Distribution. In: Belnap J, Lange OL, editors. Biological Soil Crusts: Structure, Function, and Management Ecological Studies (Analysis and Synthesis). Springer, Berlin, Heidelberg; 2001. p. 3-30.

[33] Corenblit D, Steiger J. Vegetation as a major conductor of geomorphic changes on the Earth surface: toward evolutionary geomorphology. Earth Surf Process Landforms. 2009;34(6):891-6.

[34] Cappitelli F, Sorlini C. Microorganisms Attack Synthetic Polymers in Items Representing Our Cultural Heritage. Appl Environ Microbiol. 2008;74(3):564-9.

[35] Sohrabi M, Favero-Longo SE, PérezOrtega S, Ascaso C, Haghighat Z, Talebian $\mathrm{MH}$, et al. Lichen colonization and associated deterioration processes in Pasargadae, UNESCO world heritage site, Iran. Int Biodeterior Biodegradation. 2017;117:171-82.

[36] Benedict JB. A Review of Lichenometric Dating and Its Applications to Archaeology. Am Antiq. 2009;74(1):14372.

[37] Gazzano C, Favero-Longo SE, Matteucci E, Roccardi A, Piervittori R. Index of Lichen Potential Biodeteriogenic Activity (LPBA): A tentative tool to evaluate the lichen impact on stonework. Int Biodeterior Biodegradation. 2009;63(7):836-43.

[38] Seaward MRD. Lichens as Agents of Biodeterioration. In: Upreti DK, Divakar PK, Shukla V, Bajpai R, editors. Recent Advances in Lichenology. New Delhi: Springer India; 2015. p. 189-211.

[39] Adamo P, Violante P. Weathering of rocks and neogenesis of minerals associated with lichen activity. Appl Clay Sci. 2000;16(56):229-56.

[40] Viles HA, Cutler NA. Global environmental change and the biology of heritage structures. Glob Chang Biol. 2012;18(8):2406-18.

[41] Dyda M, Decewicz P, Romaniuk K, Wojcieszak M, Sklodowska A, Dziewit L, et al. Application of metagenomic methods for selection of an optimal growth medium for bacterial diversity analysis of microbiocenoses on historical stone surfaces. Int Biodeterior Biodegradation. 2018;131:2-10.

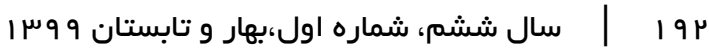




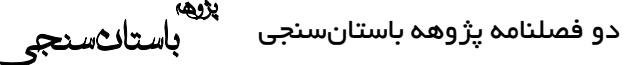

